\title{
POLITICAL DECISION PROCESSES, TRANSPORTATION INVESTMENT AND CHANGES IN URBAN LAND USE: A SELECTIVE BIBLIOGRAPHY WITH PARTICULAR REFERENCE TO AIRPORTS AND HIGHWAYS
}

WILLIAM D. CHIPMAN HARRY P. WOLFE PAT BURNETT

\section{RESEARCH REPORT 7}

MARCH 1974

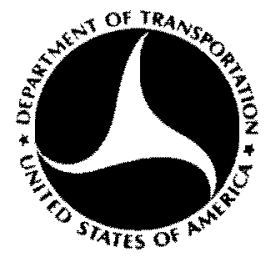

DEPARTMENT OF TRANSPORTATION OFFICE OF UNIVERSITY RESEARCH WASHINGTON, D.C. 20590

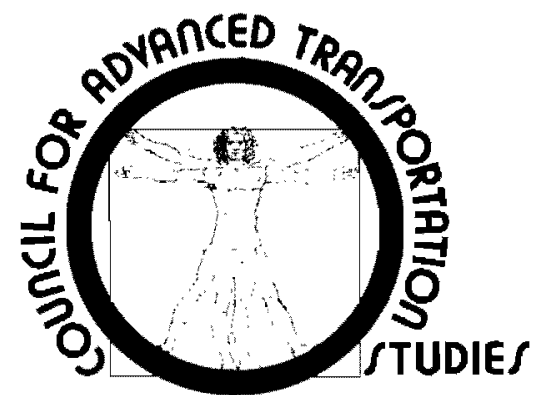

The University of Texas at Austin 


\title{
POLITICAL DECISION PROCESSES, TRANSPORTATION INVESTMENT AND CHANGES IN URBAN LAND USE: A SELECTIVE BIBLIOGRAPHY WITH PARTICULAR REFERENCE TO AIRPORTS AND HIGHWAYS
}

\author{
WILLIAM D, ChIPMAN \\ HARRY P. WOLFE \\ PAT BURnetT
}

\author{
MARCH 1974 \\ RESEARCH REPORT \\ Document is available to the public through the \\ National Technical Information Service, \\ Springfield, Virginia 22151 \\ PREPARED FOR
}

COUNCIL FOR ADVANCED TRANSPORTATION STUDIES

THE UNIVERSITY OF TEXAS AT AUSTIN

AUSTIN, TEXAS 78712

IN COOPERATION WITH

DEPARTMENT OF TRANSPORTATION

OFFICE OF UNIVERSITY RESEARCH

WASHINGTON, D.C. 20590 
NOTICE

This document is disseminated under the sponsorship of the Department of Transportation, Office of Untversity Research, in the interest of information exchange.

The United States Government, and the University of Texas assume no liabllity for its contents or use thereof. 
Techaieal Report Documentetion Poge

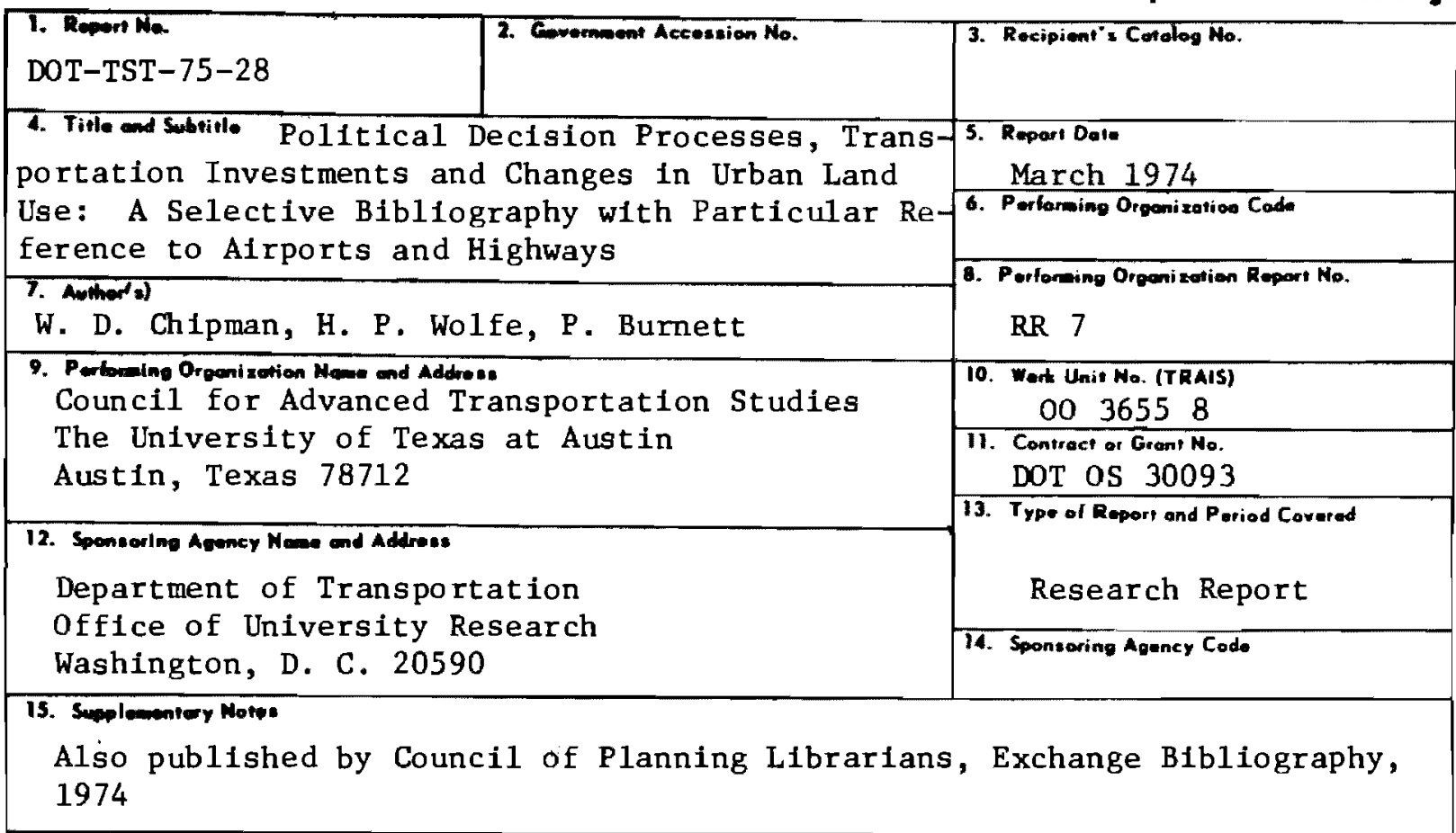

16. Abitrect

The purpose of this Bibliography is to assist with the revision and extension of intra-urban location theory, so as to explain and predict how decisionmaking by different persons and groups affects change in intra-urban land use. Special attention is paid to the generation and resolution of conflicts over urban land in the vicinity of new transportation facilities. In particular the Bibliography focuses on new airports on rural-urban fringes and the conflicts generated between politicians, citizens' and business groups, and planners over land use in their vicinity Existing literature is sparse on this topic.

17. Kay Words

Bibllography; political decision processes; transportation investment and changes in urban land use: airports; highways.
11. Diatribution Starcoment

Document is available to the public through the National Technical Information Service, Springfield, Virginia 22151

\begin{tabular}{|c|c|c|c|}
\hline 19. Secendity Clessif. (of this mpeet) & D. Security Closulf. (of thi e poes) & 21. No. of Poges & 22. Price \\
\hline Unclassifie & Unclassified & 73 & \\
\hline
\end{tabular}




\section{EXECUTIVE SUMMARY}

\section{INTRODUCTION}

In recent years, there has been a decline of interest in aggregate models of urban growth and land use. Such models attempt to describe or predict the locations of categories of activity at the metropolitan or citywide scale, 1 and most fail to fit realworld situations well. ${ }^{2}$ This obviously limits the current ability of policy makers to understand urban growth processes and to prescribe for them.

One reason for the failure of traditional models is that they rest on unrealistic assumptions about the nature of decisionmaking. For example, in classical urban land-use-land-rent models, following Hurd ${ }^{3}$ and Alonso, 4 human beings are governed in their decisionmaking by the desire to maximize money profits. They are also endowed with perfect knowledge about all past and $f u t u r e$ events which could bear on their calculations.

The desire to produce models without such unrealistic assumptions has led to attempts to identify realworld decision processes, and to suggest how they influence location decisions and hence the shaping of urban land use and growth. Thus, Brown and Moore in 1967 published a paper attempting to relate decisions by individuals about housing to the development of residential areas of different kinds within the city. In 1969 and 1973, work by Cox and Golledge 5 and Briggs ${ }^{6}$ suggested that the explanation and prediction of the location of

1. For example, w. Alonso, Location and Land Use. Toward a General Theory of Land Rent, Honolulu, 1966.

2. Many of the reasons for this are reviewed in D. Lee, 'Requiem for Large-Scale Mode1s," Journal of the American Institute of Planners, 39, 1973, 163-178.

3. R.M. Hurd, Principles of City Land Values, New York, 1903.

4. Alonso, op. cit.

5. K.R. Cox and R.G. Golledge, eds., Behavioral Problems In Geography, Northwestern University Studies in Geography, 17, 1969, 35-68.

6. R.G. Golledge and R. Briggs, "Dectston Processes and Locational Behavior," High Speed Ground Transportation, 7, 1973, 81-100. 
all kinds of activity should be approached this way. This work clearly shifts attention from macro-to-micro scale studies of urban areas, as also endorsed by Lee. ${ }^{7}$

To date, however, no mathematical, deductive analytical models have appeared to show how realworld decision processes create urban land use change in even small sections of the city.

\section{PROBLEM STUDIED}

This Bibliography has therefore been compiled to assist with the task of defining better models, as suggested above. Its emphasis is on literature which identifies the interests and values of different individuals and groups, and which traces how clashes between differing persons lead finally to decisions about the use of urban sites. Since conflicts between different parties and their resolution are political in nature - in the broad sense of political, that is, prinarily affected by group or individual power - urban land use or activity location decisionmaking is here itself categorized as political. 8 Special attention is paid to the effects of transportation investment on such political decisionmaking concerning the use of urban land. This is because it is now well-known that urban land use decisions are highly dependent on decisions about transportation.

In sum, therefore, this Bibliography is primarlly concerned with smal1scale studies of how political decision processes might result in the transformation of land from one use to another.

7. D. Lee, op. cit.

8. See discussions of Intra-urban locational decisions as political processes In this sense in:

K. Cox, Conflict, Power and Politics in the Clty: A Geographlc View, New York, 1973, and

D. Harvey, Society, the City and the Space-Economy of Urbanism, Association of American Geographers, Coumisgion on College Geography, Resource Paper Number 18, Washington, 1972 . 


\section{RESULTS ACHIEVED}

Part I focuses on urban political decision processes in general, in Sections 1.1 to 1.3 . However, three specific kinds of processes are also identified from the literature. They are: (1) decisionmaking by voters, politicians and political parties, (administrative, Section 1.4), (2) decisionmaking by citizen's pressure groups (citizens' participation, Section 1.5) and (3) decisionmaking by civil servants, especially planners (bureaucratic decisionmaking, Section 1.6). Very little of the literature on any of these topics has yet linked decision processes with urban land use change, even in verbal form.

Part II of the Bibliography focuses on how transportation investment, especially, might affect decisionmaking and urban growth. Most of the pertinent literature is concerned with highways (Section 2.3). However, this could comprise a useful source of concepts and methods to transfer to the study of the effects of transportation investment in general, and other modes of transportation in particular. Expecially, studies of the effects of airport investment might be made, since Section 2.2 of the Bibliography suggests that these effects are among the less-well known, and may be extremely important. Federal or State governments in the U.S.A. and elsewhere have recently begun to subsidize airports at high levels of investment in ruralurban areas, as part of national airport networks. (For example, the new Dallas-Fort Worth airport, Texas, U.S.A., covers 16,950 acres and is expected to cost several billion dollars by 1990 .

obviously, although this Bibliography has been compiled from a number or sources, many references may have been inadvertently omitted. References on traditional urban land use theory, urban land use planning and transportation planning have been consciously omitted: they are already covered in a number of Bibliographies, and they do not emphasize the relationships between political decisionmaking, as defined herein, and urban growth. 


\section{UTILIZATION OF RESULTS}

This Bibliography has been published by the Counctl for Planning Librarians, Exchange Bibliography Series. It is apparently being used by all levels of researchers and practitioners in their attempts to find literature, techniques, etc. which will help them deal with the difficult problem of relating political decisionmaking to urban growth.

\section{CONCLUSION}

The purpose of this Bibliography is to assist with the revision and extension of intra-urban location theory, in order to explain and predict how decisionmaking by different persons and groups affects change in intraurban land use. Special attention is paid to the generation and resolution of conflicts over urban land in the vicinity of new transportation facilities. In particular, the Bibliography focuses on new airports on rural-urban fringes, and the conflicts generated between politicians, citizens' and business groups, and planners over land use in their vicinity. Existing literature is sparse on this topic. 
PREFACE

In recent years, there has been a decline of interest in aggregative models of urban growth and land use. Such models attempt to describe or predict the locations of categories of activity at the metropolitan or citywide scale ${ }^{1}$, and most fail to fit realworld situations well. ${ }^{2}$ This obviously limits the current ability of policy makers to understand urban growth processes and to prescribe for them.

One reason for the failure of traditional models is that they rest on unrealistic assumptions about the nature of decisionmaking. For example, in classical urban land-use-land-rent models, following Hurd ${ }^{3}$ and Alonso ${ }^{4}$, human beings are governed in their decisionmaking by the desire to maximize money profits. They are also endowed with perfect knowledge about all past and future events which could bear on their calculations.

The desire to produce models without such unrealistic assumptions has led to attempts to identify realworld decision processes, and to suggest how they influence location decisions and hence the shaping of urban land use and growth. Thus, Brown and Moore in 1967 published a paper attempting to relate decisions by individuals about housing to the development of residential areas of different kinds within the city. In 1969 and 1973, work by Cox and Golledge 5 and Golledge and Briggs ${ }^{6}$ suggested that the explanation and prediction of the

1. For example, W. Alonso, Location and Land Use. Toward a General Theory of Land Rent, Honolulu, 1966.

2. Many of the reasons for this are reviewed in D. Lee, "Requiem for Large-Scale Models," Journal of the American Institute of Planners, 39, 1973, 163-178.

3. R.M. Hurd, Principles of City Land Values, New York, 1903.

4. Alonso, op. cit.

5. R.R. Cox and R.G. Golledge, eds., Behavioral Problems in Geography, Northwestern University Studies in Geography, 17, 1969, 35-68.

6. R.G. Golledge and R. Briggs, "Decision Processes and Locational Behavior," High Speed Ground Transportation, 7, 1973, 81-100. 
location of all kinds of activity should be approached this way. This work clearly shifts attention from macro- to micro- scale studies of urban areas, as also endorsed by Lee. ${ }^{7}$

To date, however, no mathematical, deductive analytical models have appeared to show how realworld decision processes create urban land use change in even small sections of the city. This Bibliography has therefore been compiled to assist with this task. Its emphasis is on literature which identifies the interests and values of different individuals and groups, and which traces how clashes between differing persons lead finally to decisions about the use of urban sites. Since conflicts between different parties and their resolution are political in nature - in the broad sense of political, that is, primarily affected by group or individual power - urban land use or activity location decision-making is here itself categorized as political. ${ }^{8}$ Special attention is paid to the effects of transportation investment on such political decisionmaking concerning the use of urban land. This is because it is now well-known that urban land use decisions are highly dependent on decisions about transportation.

In sum, therefore, this Bibliography is primarily concerned with sma11scale studies of how political decision processes might result in the transformation of 1 and from one use to another.

Part I focuses on urban political decision processes in general, in Sections 1.1 to 1.3. However, three specific kinds of processes are also identified from the 1iterature. They are: (1) decisionmaking by voters, politicians and political parties, (administrative, Section 1.4), (2) decisionmaking by citizen's pressure groups (citizens' participation, Section 1.5), and (3) decisionmaking by civil servants, especially planners (bureaucratic decisionmaking, Section 1.6).

7. D. Lee, op. cit.

8. See discussions of intra-urban locational decisions as political processes in this sense in:

R. Cox, Conflict, Power and Politics in the City: A Geographic View, New York, 1973, and

D. Harvey, Society, the City and the Space-Economy of Urbanism, Association of American Geographers, Commission on College Geography, Resource Paper Number 18, Washington, 1972 . 
Very little of the literature on any of these topics has yet linked decision processes with urban land use change, even in verbal form.

Part II of the Bibliography focuses on how transportation investment, especially, might affect decisionmaking and urban growth. Most of the pertinent literature is concerned with highways (Section 2.3). However, this could comprise a useful source of concepts and methods to transfer to the study of the effects of transportation investment in general, and other modes of transportation in particular. Especially, studies of the effects of airport investment might be made, since Section 2.2 of the Bibliography suggests that these effects are among the less-we11 known, and my be extremely important. Federal or State governments in the U.S.A. and elsewhere have recently begun to subsidize airports at high levels of investment in rural-urban areas, as part of national airport networks. (For example, the new Dallas-Fort Worth airport, Texas, U.S.A., covers 16,950 acres and is expected to cost several billion dollars by 1990).

Obviously, although this Bibliography has been compiled from a number of sources, many references may have been inadvertently omitted. References on traditional urban land use theory, urban land use planning and transportation planning have been consciously omitted: they are already covered in a number of Bibliographies, and they do not emphasize the relationships between political decisionmaking, as defined herein, and urban growth.

Pat Burnett 


\section{ACKNOWLEDGEMENTS}

The authors wish to acknowledge the professional assistance of Ms. M. Roi, Chief Librarian, Transportation Centre Library, Northwestern University, Evanston, Illinois. Gail Dafforn also assisted with the preparation of this document for publication from manuscript drafts in varying styles and hands. Dr. John Betak must also be thanked for his help on the final steps of compiling and typing this Bibliography.

The contents of this report reflect the views of the authors, who are responsible for the facts and the accuracy of the document. The contents do not necessarily reflect the official views or policies of the Department of Transportation. This report does not constitute a standard, specification or regulation. 


\begin{abstract}
The purpose of this Bibllography is to assist with the revision and extension of intra-urban location theory, in order to explain and predict how decisionmaking by different persons and groups affects change in intra-urban land use. Special attention is paid to the generation and resolution of conflicts over urban land in the vicinity of new transportation facilities. In particular, the Bibliography focuses on new airports on rural-urban fringes, and the conflicts generated between politicians, citizens' and business groups, and planners over land use in their vicinity. Existing literature is sparse on this topic.
\end{abstract}


TABLE OF CONTENTS

$\underline{\text { PAGE }}$

Preface

(i)

Acknowledgements

(iv)

Abstract

(v)

Table of Contents

I. URBAN POLITICAL DECISION PROCESSES

1.1 General and Classical Urban Political Theory

1.2 Game Theory and Decision Processes

1.3 Simulation of Decision Processes: Techniques and Case Studies

1.4 Loca1 Government

1.5 Citizens' Participation, Conflicts and Community Power Structure

1.6 Decisionmaking and the Bureaucracy

II.URBAN TRANSPORTATION INVESTMENT AND ITS EFFECTS

2.1 Urban Transportation Policy-Making: General

2.1.1 Administration

2.1.2 P1anning

2.1.3 Public Opinion and Citizen Participation

2.1.4 Economic Effects

2.1 .5 Social Effects

2.1.6 Effects on Land Use and Land Values

2.1.7 Other Environmenta1 Effects

2.2 Airport Investment and Its Effects 34

2.2.1 Administration $\quad 34$

2.2.2 Planning 39

2.2.3 Public Opinion 41

2.2.4 Economic Effects 43 
2.2 .5 Social Effects 46

2.2.6 Effects on Land Use and Land Values 47

2.2.7 Other Environmental Effects 50

2.3 Highway Investment and Its Effects 52

2.3.1 Administration 52

2.3.2 Planning 55

2.3.3 Public Opinion 56

2.3 .4 Economic Effects 61

2.3.5 Social Effects 65

2.3.6 Land Use and Land Value Effects 68

2.3.7 Other Environmental Effects 72 
I. URBAN POLITICAL DECISION PROCESSES

1,1 General and Classica1 Urban Politica1 Theory

1. Alker, H.R., Jr. Mathematics and Politics, (MacMillan, New York), 1965.

2. Aldrich, H. "Organizational Boundaries and Interorganizational Conflict," Human Relations, 24, 1971, 279-294.

3. Ashford, D.E. Comparative Urban Politics and Urbanization, Exchange Bib1iography, No. 428, (Council of Planning Librarians, Montice1lo, Illinois), 1973 .

4. Banfield, E.C. Political Influence, (Free Press, New York), 1961.

5. Barnett, J.R. and J. Mercer. Urban Political Analysis and New Directions in Political Geography, (Department of Geography, University of Iowa, Iowa City, Iowa), 1973.

6. Bauer, R.A. and K.J. Gergen. The Study of Policy Formation, (Free Press, New York), 1968.

7. Blake, R.R. Group Dynamics - Key to Decisionmaking, (Gulf Publishing Company, Houston, Texas), 1961 .

8. Bollens, J.C. and H.J. Schmandt. The Metropolis: Its People, Politics and Economic Life, (Harper and Row, New York), 1970.

9. Brinkers, H.S., ed. Decision-making: Creativity, Judgement and Systems, (Ohio State University Press, Columbus, Ohio), 1972.

10. Brock, B.L., ed. Public Policy Decision-making; Systems Analysis and Comparative Advantages Debate, (Harper and Row, New York), 1972.

11. Buchanan, W. Understanding Political Variables, (Scribner, New York), 1969.

12. Campbe11, A.K. and S. Sacks. Metropolitan America: Fisca1 Patterns and Governmenta1 Systems, (Free Press, New York), 1967.

13. Claunch, J.M., ed. Mathematica1 Applications in Politica1 Science, Conference on Mathematical Applications in Political Science, (Arnold Foundation, Southern Methodist University, Dallas), 1965.

14. Conn, P.H. Conflict and Decision-making; An Introduction to Political Science, (Harper and Row, New York), 1971. 
15. Coulter, P.B., ed. Politics of Metropolitan Areas: Selected Readings, (Thomas Y. Cromwe11, New York), 1967.

16. Davis, M. and M.G. Weinbaum. Metropolitan Decision Processes; An Analysis of Case Studies, (Rand McNa1ly, Chicago), 1969.

17. Davis, O.A. and M. Hinich. "A Mathematical Model of Policy Formation in Democratic Society," in J.L. Berend, ed., Mathematical Applications in Political Science II, (Southern Methodist University Press, Dallas), $1966,175-208$.

18. Davis, O.A. and M. Hinich. "Some Results Related to a Mathematical Model of Policy Formation in Democratic Society," in J.L. Berend, ed., Mathematical Applications in Political Science III, (University Press of Virginia, Charlottesvi11e), 1967, 14-38.

19. DeBlij, J.H. Systematic Political Geography, (John Wiley and Sons, New York), 1967.

20. De Torres, J. Government Services in Major Metropolitan Areas; Functions, Costs, Efficiency, (The Conference Board, New York), 1972.

21. Dreyer, E.C. and W.A. Rosenbaum, eds. Political Opinion and Electoria1 Behavior; Essays and Studies, (Wadsworth Publishing Company, Belmont, California), 1966.

22. Duh 1, L. De1iberate Socia1 Change in the City: List of Suggested Readings, Exchange Bibliography, No. 250, (Council of Planning Librarians, Montice11o, I11inois), 1972 .

23. Duncan, R.B. Multiple Decision-making Structures in Adapting to Environmenta1 Uncertainty," Human Relations, 26, 1973, 273-292.

24. Dye, T. and B.W. Hawkins, eds. Politics in the Metropolis, (Charles E. Merrill Publishing Company, Columbus, Ohio), 1967.

25. Easton, D.A. A Framework for Political Analysis, (Prentice-Ha11, Englewood Cliffs, New Jersey), 1965.

26. Edelstein, J.D. and M. Warner. "Voting and Allied Systems in Group-Decisionmaking (Their relationship to innovation, competition, and conflict resolution)," Human Relations, 24, 1971, 179-188.

27. Festinger, L. and V. Allen. Conflict, Decision, and Dissonance, (Stanford University Press, Stanford, California), 1964.

28. Francis, W.L. Forma1 Mode1s of American Politics: An Introduction, (Harper and Row, New York), 1972.

29. Freeman, L.C. et. a1. Metropolitan Decision Making, (University College of Syracuse, Syracuse, New York), 1962.

30. Garson, G.D. Handbook of Political Science Methods, (Holbrook Press, Boston), 1971 . 
31. Gordon, D.M., ed. Problems in Political Economy: An Urban Perspective, (Heath, Lexington, Massachusetts), 1971.

32. Graham, G.J. Methodologica1 Foundations for Political Ana1ysig, (Xerox College Publishers, Waltham, Massachusetts), 1971.

33. Harvey, D. Society, the City and the Space-Economy of Urbanism, Commission on College Geography Resource Paper No. 18, (Association of American Geographers, Washington), 1972 .

34. Hawley, A.H. and B.G. Zimmer. The Metropolitan Community; Its People and Government, (Sage Publications, Beverly Hil1s, California), 1970.

35. Isard, W. et. a1. General Theory; Socia1, Politica1, Economic and Regional With Particiular Reference to Decision Making Analysis, Regional Science Study Series No. 8, (Massachusetts Institute of Technology Press, Cambridge), 1969.

36. Johnson, E. Studies in Multiobjective Decision Models, (Studentlitteratur, Lund ), 1968 .

37. Kaplan, H. Urban Political Systems: A Functional Analysis of Metropolitan Toronto, (Columbia University Press, New York), 1967.

38. Keeney, R.L. "A Decision Analysis With Multiple Objectives," Bell Journal of Economic and Management Science, 4, 1973, 101-117.

39. Kramer, G.H. "On a Class of Equilibrium Conditions for Majority Rule," Econometrica, 41, 1973, 285-298.

40. Lee, W. Decision Theory and Human Behavior, (Wiley, New York), 1971.

41. Lineberry, R.L. and I. Sharilansky. Urban Politics and Public Policy, (Harper and Row, New York), 1971.

42. Long, N. "Political Science and the City," in L.F. Schnore, ed., Social Science and the City, (F.A. Praeger, New York), 1968, 243-262.

43. Maguire, L.M. An Annotated Bibliography of the Literature on Change, Exchange Bibliography, No, 216-217, (Council of Planning Librarians, Monticello, Illinois), 1971.

44. McCandless, C.A. Urban Government and Politics, (McGraw-Hi11, New York), 1970.

45. McMillan, C. and R.F. Gonzalaz. Systems Analysis; A Computer Approach to Decision Mode1s, (R.D. Irwin, Homewood, I11inois), 1968.

46. Mine, H. and S. Osaki. Markovian Decision Processes, (American E1sevier Publishing Company, New York), 1970. 
47. Nimo, D. and T. Ungs. American Political Patterns, (Little, Brown and Company, Boston), 1967 .

48. Patterson, C.C., Jr. Selected Bibliographies of Planning, Politics, and Politica1 Science, Exchange Bibliography, No. 24, (Council of Planning Librarians, Montice11o, I11inois), 1963.

49. Riker, W.H., and P.C. Ordeshook. An Introduction to Positive Political Theory, (Prentice-Ha11, Englewood Cliffs, New Jersey), 1973.

50. Rivett, P. Principles of Mode1 Building: The Construction of Models for Decision Analysis, (Wiley, New York), 1972.

51. Robinson, I.M. ed. Decision-making in Urban P1anning; An Introduction to New Methodologies, (Sage Publications, Beverly Hi11s, California), 1972 .

52. Suppes, P.C. and R.C. Atkinson. Markov Learning Models For Multiperson Interactions, (Stanford University Press, Stanford, California), 1960.

53. Syed, A. The Political Theory of American Loca1 Government, (Random House, New York), 1966.

54. Tiebout, C.M. "A Pure Theory of Local Expenditures," Journal of Political Economy, 64, 1956, 416-424.

55. Tullock, G. Toward a Mathematics of Politics, (University of Michigan Press, Ann Arbor, Michigan), 1967.

56. White, D.J. Decision Theory, (Aldine Publishing Company, Chicago), 1969.

57. Williams, D.F. Urban Socia1 Planning: A Selected Bibliography, Exchange Bibliography, No. 458, (Council of Planning Librarians, Monticello, Illinois), 1973.

58. Williams, O.P. Metropolitan Political Analysis; A Social Access Approach, (Free Press, New York), 1971. 


\subsection{Game Theory and Decision Processes}

1. Aitchison, J. Choice Against Chance: An Introduction to Statistical Decision Theory, (Addison-Wesley Publishing Company, Reading, Massachusetts), 1970 .

2. Berkman, H.G. "The Game Theory of Land Use Determination," Land Economics, XLI, $1965,11-20$.

3. Blackwe11, D. and Girshich, M. Theory of Games and Statistical Decisions, (John Wiley and Sons, New York), 1954.

4. Blaquiere, A., F. Gerard, and G. Leitmann. Quantitative and Qualitative Games, (Academic Press, New York), 1969.

5. Davis, M.D. Game Theory: A Nontechnical Introduction, (Basic Books, New York), 1970 .

6. Deutsch, K.W. "Game Theory and Politics: Some Problems of Application," Canadian Journal of Economic and Political Science, 20, 1954.

7. Feldt, A.G., ed. Selected Papers on Operational Gaming, (Division of Urban Studies, Cornell University, Ithaca, New York), 1966.

8. Grawoig, D.E. Decision Mathematics, (McGraw-Hil1, New York), 1967.

9. Helmer - Hirschberg, 0. Multipurpose Planning Games, (Institute for the Future, Menlo Park, California), 1971.

10. Howard, N. Paradoxes of Rationality: Theory of Metagames and Political Behavior, (Massachusetts Institute of Technology Press, Cambridge), 1971.

11. Isard, W. "Game Theory, Location Theory and Industrial Agg lomeration", Papers, Regional Science Association, $18,1967,1-11$.

12. Isard, W. "Location Games With Application to Classic Location Problems," in W. Isard, et. al. General Theory: Social, Political, Economic and Regional, (Massachusetts Institute of Technology Press, Cambridge), 1969, 430-490.

13. Lowenstein, L.K. An Annotated Bibliography on Urban Games, Exchange Bibliography, No. 204, (Council of Planning Librarians, Monticello, Illinois), 1971.

14. Luce, R.D. and H. Raiffa. Games and Decisions: Introduction and Critical Survey, (John Wiley and Sons, New York), 1957.

15. Owen, G. Game Theory, (Saunders, Philadelphia), 1968. 
16. Paquette, N. and P. Frankland. A Discussion of Decision Making Under Conditions of Environmental Uncertainty, (Department of Geography, University of Iowa, Iowa City, Iowa), 1973.

17. Riker, W.H. "Experimental Verification of Two Theories About n-Person Games," in J.L. Berend, ed., Mathematical Applications in Political Science, III, (University Press of Virginia, Charlottesvi11e), 1967, 52-66.

18. Riker, W.H. The Theory of Political Coalitions, (Yale University Press, New York), 1962 .

19. Shubik, M., ed. Game Theory and Related Approaches to Social Behavior; Selections, (Wiley and Sons, New York), 1964.

20. Shubik, M., ed. Readings in Game Theory and Political Behavior, (Doubleday, New York), 1954 .

21. Smith, P.A. "The Games of Community Politics," Midwest Journal of Politica1 Science, 9, 1965, 37-60.

22. Von Neumann, J, and O. Morgenstern. Theory of Games and Economic Behavior, (Princeton University Press, Princeton), 1953. 


\subsection{Simulation of Decision Processes: Techniques and Case Studies}

1. American Society for Cybernetics, Cybernetics, Simulation, and Conflict Resolution, (Spartan Books, New York), 1971.

2. Barton, R.F. "Incorporating Qualitative Judgements into Man-Computer Simulations," Simulation and Games, 3, 1972, 79-88.

3. Barton, R.F. A Primer on Simulation and Gaming, (Prentice-Ha11, Englewood Cliffs, New Jersey), 1970.

4. Berger, E., H. Bonlag, and B. Zisk. "Simulation and the City: A Critical Overview," Simulation and Games, 1, 1969, 411-428.

5. Berger, E.,H. Boulay and B. Zisk. "URBOS: A Simulation of Urban Political Process," in B.H. Zisk, ed., American Political Interest Groups: Readings in Theory and Research, (Wadsworth, Belmont, California), 1969.

6. Bonini, C. P. Simulation of Information and Decision Systems in the Firm, (Prentice-Hall, Englewood Cliffs, New Jersey), 1963.

7. Clarke, W. "A Research Note on Simulation in the Social Sciences," Simulation and Games, 1, 1969, 203-210.

8. Coplin, W.D., ed. Simulation in the Study of Politics, (Markham Publishing Company, Chicago), 1968.

9. Drackman, D. "Understanding the Operation of Complex Socia1 Systems: Some Uses of Simulation Design," Simulation and Games, 2, 1970, 173-196.

10. Duke, R.D. Gaming Simulation In Urban Research, (Institute for Community Development and Services, Michigan State University, East Lansing, Michigan), 1964.

11. Fletcher, J.L. "Simulations as Research Tools," Simulation and Games, 4, $1973,341-343$.

12. Francis, W. "Simulation of Committee Decision-making in a State Legislative Body," Simulation and Games, 1, 1969, 235-262.

13. Gamson, W.A. "SIMSOC: Establishing Social Order in a Simulated Society," Simulation and Games, 2, 1969, 287-308.

14. Gamson, W.A. SIMSOC: Simulated Society; A Participant's Manual with Selected Readings, (Free Press, New York), 1972.

15. Greenblat, C.S. "Gaming and Simulation in the Social Sciences: A Guide to the Literature," Simulation and Games, 3, 1972, 477-491. 
16. Guetzkow, H.S., ed. Simulation in Social and Administrative Science; Overviews and Case-Examples, (Prentice-Ha11, Englewood Cliffs, New Jersey), 1972 .

17. Guetzkow, H., ed. Simulation in Social Sciences: Readings, (PrenticeHa11, Englewood C1iffs, New Jersey), 1962.

18. Gullahorn, J.E. and J.T. "Simulation and Social System Theory: The State of the Union," Simulation and Games, 1, 1969, 19-42.

19. Guthrie, H.W. 'Microanalytic Simulation Modeling for Evaluation of Public Policy," Urban Affairs Quarterly, 7, 1972, 403-418.

20. Hare, A.P. "Simulating Group Decision," Simulation and Games, 1, 1969, $361-376$.

21. Harris, B. "The Uses of Theory in the Simulation of Urban Phenomena," Highway Research Record No. 124, (Highway Research Board, Washington), 1966 .

22. Hemmens, G.D. Urban Development Modeling Seminar No. 1:Application of Computer Simulation Techniques to Social and Political Decisionmaking, (George Washington University, Washington ), 1970.

23. Herrick, C.S. "Simulation of a Simple Legislature," Simulation and Games, $2,1970,405-424$.

24. Kibe1, B.M. Simulation of the Urban Environment, (Association of American Geographers, Washington), 1972 .

25. Laponce, J.A. and P. Smoken. Experimentation and Simulation in Political Science, (University of Toronto Press, Toronto), 1972.

26. McMillan, C. and R.F. Bonzalez. Systems Analysis: A Computer Approach to Decision Models, (Richard D. Irwin, Incorporated, Homewood, Il1inois), 1968 .

27. Mazur, A. "Simulation Validity," Simulation and Games, 4, 1973, 344-346.

28. Mihram, G.A. Simulation: Statistical Foundations and Methodology, (Academic Press, New York), 1972.

29. Nagelberg, M. Simulation of Urban Systems: A Selected Bibliography, (Institute for the Future, Middletown, Connecticut), 1970.

30. Nagelberg, M. and D.L. Little. "Selected Urban Simulations and Games," Simulation and Games, 1, 1969, 459-482.

31. Schran, H. "Urban Systems Gaming: Developments in Germany, " Simulation and Games, 3, 1972, 291-308.

32. Taylor, J.L. Instructional Planning Systems: A Gaming Simulation Approach to Urban Problems, (University Press, Cambridge, England), 1971. 
33. Vogel, R. "The Effect of a Simulation Game on the Attitude of Political Efficacy," Simulation and Games, 4, 1973, 71-80.

34. Wisconsin University Social Systems Research Institute, Program Simulate II; A User's and Programmer's Manual, (Social Systems Research Institute, Computation Division, Madison, Wisconsin), 1967.

35. Wo1f, C.P. "SIMCANSOC: Simulated Canadian Society," Simulation and Games, $3,1972,53-78$. 


\subsection{Local Government}

1. Adrian, C.R. State and Local Government, A Study in the Political Process, (McGraw-Hil1, New York), 1960.

2. Agger, R.E. and V. Ostrom. "The Political Structure of a Sma11 Community," Public Opinion Quarterly, 20, 1956, 81-89.

3. Agger, R.E., D. Goldrich and B.E. Swanson. The Rulers and the Ruled; Political Power and Impotence in American Communities, (Wiley, New York), 1964 .

4. Bouma, D.H. "Legitimation of the Social Power Position of a Real Estate Board," American Journal of Economics and Sociology, 21, 1962, 383-392.

5. Bromage, A.W. Urban Policy Making: The Council-Manager Partnership, (Public Administration Service, Chicago), 1970.

6. Cox, K,R. "The Spatial Structuring of Information Flow and Partisan Attitudes," in M. Dogon and S.R. Okkon, eds., Quantitative Ecologica1 Analysis in the Social Sciences, (Massachusetts Institute of Technology Press, Cambridge), 1969, 157-186.

7. Cox, K.R. "The Spatial Components of Urban Voting Response Surfaces," Economic Geography, 47, 1971, 27-35.

8. Downes, B.T. Cities and Suburbs; Selected Readings in Local Politics and Public Policy, (Wadsworth Publishing Company, Belmont, California), 1971 .

9. Dye, T. Politics in States and Communities, (Prentice-Ha11, Englewood Cliffs, New Jersey), 1973.

10. Dykstra, R.R. "Stratification and Community Political Systems," American Behavioral Scientist, $16,1973,695-714$.

11. F1inn, T.A. Local Government and Politics, (Scott, Foresman, Glenview, I11inois), 1969.

12. Foley, J.W. The Structural Determinants of Public Policy: An Internationa1, Mu1ti-Disciplinary Bibliography, Exchange Bibliography, No - 508, (Council of Planning Librarians, Monticello, Illinois), 1973.

13. Gilbert, C.E. Governing the Suburbs, (Indiana University Press, Bloomington, Indiana), 1967.

14. Grant, D.R. and H.C. Nixon. State and Loca1 Government in America, (A11yn and Bacon, Boston), 1968. 
15. Hahn, H. "Influencing Public Officials," in H. Hahn, ed., People and Politics in Urban Society, Part II, (Sage Publications, Bever1y Hills, California),1972, 171-278.

16. Hale, C.W. "Impact of Federal Policy and Technological Change on Regional and Urban Planning Problems," Land Economics, 47, 1971, 2435 .

17. Hawkins, B.W. Politics and Urban Policies, (Bobbs-Merrill Company, New York), 1971.

18. Hirsch, W.Z. and S. Sonenblum. Governing Urban America in the 1970's, (Praeger, New York), 1973.

19. Kuo, W.H. "Mayoral Influence in Urban Policy Making," American Journal of Sociology, 79, 1973, 620-638.

20. Levenson, R. The Legislative Role in Urban Affairs: A Bibliography, Exchange Bibliography, No. 361, (Council of P1anning Librarians, Monticello, Illinois), 1973.

21. Levenson, R. Women in Government and Politics: A Bibliography of American and Foreign Sources, Exchange Bibliography, No, 491, (Council of Planning Librarians, Monticello, Illinois), 1973.

22. Mi11s, W.E., Jr. and H.R. Davis. Sma11 City Government: Seven Cases in Decision-making, (Random House, New York), 1968.

23. Morgan, D.R. and S.A. Kirkpatrick, eds. Urban Political Analysis: A Systems Approach, (Free Press, New York), 1972.

24. Press, C. Main Street Politics: Policy Making at the Local Level, (Institute for Community Development, East Lansing, Michigan), 1962.

25. Raymond and May Associates. Zoning Controversies in the Suburbs: Three Case Studies, (United States Government Printing Office, Washington), 1968.

26. Reymolds, D.R. and J.C. Archer. "An Inquiry into the Spatial Basis of Electoral Geography," Discussion Paper 11, Department of Geography, University of Iowa, 1969.

27. Riede1, J.A. New Perspectives in State and Local Politics, (Xerox College Publishers, Waltham, Massachusetts), 1971.

28. Stedman, M.S. Urban Politics, (Winthrop Publishers, Cambridge, Massachusetts), 1972 .

29. Straayer, J.A. American State and Local Government, (C.E. Merrill, Columbus, Ohio), 1973.

30. Wickwar, W.H. The Political Theory of Local Government, (University of South Carolina Press, Columbia), 1970.

31. Wilson, J.Q., ed. City Politics and Public Policy, (Wiley, New York), 1968. 


\subsection{Citizen's Participation, Conflicts and Community Power Structure}

1. Aberbach, J.D. and J.L. Walker. "Citizen Desires, Policy Outcomes, and Community Control," Urban Affairs Quarterly, 8, 1972, 55-76.

2. Aiken, M. "The Distribution of Community Power: Structural Bases and Social Consequences," in M. Aiken, et. al., ed., The Structure of Community Power, (Random House, New York), 1970, 487-526.

3. Alford, R.R. and H.M. Scoble. "Community Leadership, Social Status, and Political Behavior," American Sociological Review, 33, 1968, 259-271.

4. Alford, R.R. Bureaucracy and Participation: Political Cultures in Four Wisconsin Cities, (Rand McNa11y, Chicago), 1969.

5. Alinsky, S.D. Reveille for Radicals, (Vintage Books, New York), 1969, c. 1946 .

6. Alinsky, S.D. Rules for Radica1s; A Practical Primer for Realistic Radicals, (Random House, New York), 1971.

7. Altshuler, A.A. The Ancker Hospital Site Controversy, (Bobbs-Merri11 Company, Indianapolis, Indiana), 1964.

8. Altshuler, A.A. The C1ty Planning Process: A Political Analysis, (Cornell University Press, Ithaca, New York), 1965.

9. Altshuler, A.A. Community Control: The Black Demand for Participation in Large American Cities, (Pegasus, New York), 1970.

10. Altshuler, A.A. The Politics of the Federal Bureaucracy, (Dodd, Mead, New York), 1971, c. 1968.

11. Ammentorp, W.M. The Influence of Social Support in Decision Making: A Study of Primary Groups, Unpublished thesis, University of Colorado, 1964.

12. Blankenship, L.V. "Community Power and Decision-making: A Comparative Evaluation of Measurement Techniques," Social Forces, 43, 1964, 207-216.

13. Bolton, C.K. and K.E. Corey. A Selected Bibliography for the Training of Citizen-Agents of P1anned Community Change, Exchange Bibliography, No.125, (Council of Planning Librarians, Monticel1o, I11inois), 1970.

14. Bolton, C.K. and M.E. Lindberg. Conflict: The Conditions and Processes in Community, Organizations and Interpersonal Relationships, Exchange Bibliography, No. 187, (Council of Planning Librarians, Montice11o, Illinois), 1971 .

15. Bolton, C.K, and K.E. Corey. A Selected Bibliography for the Training of Citizen-Agents of Planned Community Change, Exchange Bibliography, No. 206, (Council of Planning Librarians, Monticello, Illinois), 1971. 
16. Botka, D. "A Descriptive Model of Social Contacts Within a Community," Ekistics, 30, 1970, 110-116.

17. Braybrooke, D. and C.E. Lindblom. A Strategy of Decision: Policy Evaluation as a Socia1 Process, (Free Press, New York), 1970.

18. Buck, R.E. Power, Ideology, and Decision-making: An Investigation in the Socia1 Psychology of Community Politics, Unpublished dissertation, University of Texas, Austin, 1970.

19. Clark, T.N., ed. Community Structure and Decision-making: Comparative Analysis, (Chandler Publishing Company, San Francisco), 1968.

20. Clark, T.N. "Power and Community Structure: Who Governs, Where, and When?," The Sociological Quarter1y, 8, 1967, 291-318.

21. Clark, W.E. Community Power and Decision-making: A Selective Bibliography, Exchange Bibliography, No. 234, (Council of Planning Librarians, Monticello, I11inois), 1971.

22. Conway, W.J. "Economic Dominants and Community Power: A Reputational and Decisional Analysis," American Journal of Economics and Sociology, 32, 1973, 269-282.

23. Cox, K. Conflict Power and Politics in the City: A Geographical View, (McGraw Hi11, New York), 1973.

24. Crain, R.L. and D.B. Rosentha1. "Community Status as a Dimension of Local Decision-making," American Sociological Review, 32, 1967, 970-984.

25. Dah1, R.A. Who Governs? Democracy and Power in an American City, (Yale University Press, New Haven), 1961.

26. Dansereau, H.K., R.A. Rehberg, and J.R. Maiolo. "Specified Social Determinants of Attitudes Toward Community Planning and Zoning," Unpublished report, Pennsylvania State University, Pittsburg, 1966.

27. D'Antonio, W.V. and W.H. Form. Influentials in Two Border Cities; A Study in Community Decision Making, (University of Notre Dame Press, Notre Dame, Indiana), 1965.

28. Field, A.J. Urban Power Structures: Problems in Theory and Research, (Schenkman Publishing Company, Cambridge, Massachusetts), 1970.

29. Freeman, L.C. Patterns of Loca1 Community Leadership, (Bobbs-Merri11, New York), 1968.

30. Gamberg, H. The Escape From Power: Politics in the American Community (A Monograph and Selected Bibliography), Exchange Bibliography, No. 106, (Council of Planning Librarians, Monticello, Illinois), 1969.

31. Gans, H.J. The Urban Villagers; Groups and Class Life of Italian-Americans, (Free Press of Glencoe, New York), 1962.

32. Gans, H.J. The Levittowners; Ways of Life and Politics in a New Suburban Community, (Pantheon Books, New York), 1967. 
33. Gans, H.J. People and Plans; Essays on Urban Problems and Solutions, (Basic Books, New York), 1968.

34. Gans, H.J. More Equality, (Pantheon Books, New York), 1973.

35. Harvey, D. "Social Processes, Spatial Form and the Redistribution of Real Income in an Urban System," Colston Papers, 22, 1971.

36. Hayes, E.C. Power Structures and Social Policy, (McGraw-Hi11, New York), 1972 .

37. Hinman, J. "Controversial Facility-Complex Programs: Coalitions, SidePayments and Social Decisions," Research on Conflict in Locational Decisions, Discussion Paper VIII, (Department of Regional Science, University of Pennsylvania, Philadelphia), 1970.

38. Hinman, J. "A Location Mode1 for Public Facilities With Neighborhood Effecto," Research on Conflict in Locational Decisions, Discussion Paper XIII, (Department of Regional Science, University of Pennsylvania, Philadelphia), 1971.

39. Hinman, J. "Towards a Spatia1 Strategy for Urban Renewa1," Research on Conflict in Locational Decisions, Discussion Paper XV, (Department of Regional Science, University of Pennsylvania, Philadelphia), 1971.

40. Hoinville, G. "Evaluating Community Preferences, " Environment and Planning, $3,1971,33-50$.

41. Hunter, F.Community Power Structure; A Study of Decision Makers, (University of North Carolina Press, Chapel Hi11, North Carolina), 1953.

42. Hunter, F., R.C. Schaffer, and C.G. Sheps. Community Organization; Action and Inaction, (University of North Carolina Press, Chapel Hill, North Carolina), 1956.

43. Jennings, M.K. "Study of Community Decision-making," in B.E. Swanson, ed., Current Trends in Comparative Community Studies, (Community Studies, Incorporated, Kansas City), 1962 .

44. Jones, H.R. Selected References for Citizen Groups Interested in Problems of Community Planning, Exchange Bibliography, No. 5, (Council of Planning Librarians, Montice11o, Illinois), 1958.

45. Kamnerer, G. and J. DeGrove. "Urban Leadership During Change," Annals, 353 , $1964,95-106$.

46. Ledyard, J. Citizen Participation in Planning, Exchange Bibliography, No. 76, (Council of Planning Librarians, Montice1lo, Illinois), 1969.

47. Levitt, M. Women's Role in American Politics, Exchange Bibliography, No. 446, (Council of Planning Librarians, Monticello, Illinois), 1973. 
48. Lindberg, M.E. Conflict: The Conditions and Processes in Community Organizations and Interpersonal Relationships, Exchange Bibliography, No. 187, (Council of Planning Librarians, Monticello, Illinois), 1971.

49. Mann, L.D. "Studies in Community Decision Making," Journal of the American Institute of P1anners, 30, 1964, 58-65.

50. Masoth, L.H. and D.R. Bowen. "Communities and Budgets: The Sociology of Municipa1 Expenditures," Urban Affairs Quarter1y, 1, 1965, 39-50.

51. May, J.V. Citizen Participation: A Review of the Literature, Exchange Bibliography, No. 210-211, (Council of Planning Librarians, Montice1lo, I11inois), 1971.

52. Mazziotti, D.F. Advocacy Planning -- Toward the Development of Theory and Strategy, Exchange Bibliography, No. 241, (Council of Planning Librarians, Monticello, I11inois), 1971.

53. Mazziotti, D.F. Advocacy Planning: A Selected Bibliography, Exchange Bibliography, No. 323, (Council of Planning Librarians, Monticello, I1linois), 1972 .

54. Miller, H.V. Citizen Participation in Planning, Exchange Bibliography, No. 76, (Council of Planning Librarians, Montice11o, Illinois), 1969.

55. Mumphrey, A.J. and J. Wolpert. "Equity Considerations and Concessions in the Siting of Public Facilities," Research on Conflict in Locationa1 Decisions, Discussion Paper XVII, (Department of Regional Science, University of Pennsylvania, Philadelphia), 1972.

56. Pellegrin, R. "Selected Bibliography on Community Power Structure," Southwestern Socia1 Science Quarterly, 48, 1967, 451-465.

57. Pierce, M.C. Participation in Decision-making: A Selected Bibliography, Exchange Bibliography, No. 258, (Council of Planning Librarians, Montice11o, I11inois), 1972.

58. Regiona1 P1an Association of New York. Public Participation in Regional Planning; A Report of the Second Regional Plan, (Regional Plan Association, New York), 1967.

59. Reiner, T.A., R.J. Sugarman, and I.E. Seley. "Citizen Participation in Planning: The Crosstown as a Case Study and Some Recommendations," Research on Conflict in Locational Decisions, Discussion Paper XII, (Department of Regiona1 Science, University of Pennsylvania, Philadelphia), 1971.

60. Rossi, P.H. and R.A. Dentler. The Politics of Urban Renewa1: The Chicago Findings, (Free Press of Glencoe, New York), 1961.

61. Sanders, M.K. The Professional Radical; Conversations with Saul Alinsky, (Harper and Row, New York), 1970.

62. Schaffer, A. and R.C. Schaffer. Woodruff: A Study of Community Decisionmaking, (University of North Carolina Press, Chapel Hil1, North Carolina), 1970 . 
63. Seley, J.E. "Participation in Urban Renewal: The German Town Case," Research on Conflict in Locational Decisions, Discussion Paper II, (Department of Regional Science, University of Pennsylvania, Philade1phia), 1970.

64. Thometz, C.E. The Decision-makers: The Power Structure of Dallas, (Southern Methodist University Press, Da11as), 1963.

65. Witt, B. Corporate Planning, An Introductory Bibliography, Exchange Bibliography, No. 484, (Council of Planning Librarians, Montice1lo, I11inois), 1973.

66. Wolpert, J. et. a1. 'Metropolitan Neighborhoods: Participation and Conflict Over Change, " Commission on College Geography, Resource Paper No. 16, (Association of American Gecgraphers, Washington, D.C.), 1972. 


\subsection{Decisionmaking and the Bureaucracy}

1. Alford, R.R. Bureaucracy and Participation: Politica1 Cultures in Four Wisconsin Cities, (Rand McNal1y, Chicago), 1969.

2. Allensworth, D.T. Public Administration; The Execution of Public Policy, (Lippincott, Philadelphia), 1973.

3. Alperovich, G. "Welfare Criteria Models for Locating Public Facilities," Research in Conflict on Locational Decisions Discussion Paper XIX, (Department of Regional Science, University of Pennsylvania, Philadelphia), 1972 .

4. American Institute of Planners. The Planner in Emerging Urban Society; A Confrontation, (American Institute of Planners, Washington), 1965.

5. Andrews, R.B. Urban Land Economics and Public Policy, (Free Press, New York), 1971.

6. Andrews, R.B. Urban Land Use Policy The Central City, (Free Press, New York), 1972 .

7. Babcock, R.F. The Zoning Game: Municipal Practices and Policies, (University of Wisconsin, Madison), 1966.

8. Bah1, R.W. Metropolitan City Expenditures: A Comparative Analysis, (University of Kentucky Press, Lexington), 1969.

9. Barnett, J.R. Political Structure, Urban Spatial Organization and The Delivery of Municipal Services, Unpublished paper, Department of Geography, University of Iowa.

10. Beetham, M.A. Consumer Participation in Comprehensive Planning, Exchange Bibliography, No. 72, (Council of Planning Librartans, Monticello, Illinois), 1969.

11. Bish, R.L. The Public Economy of Metropolitan Areas, (Markham Publishing Company, Chicago), 1971.

12. Boyce, D.E. Metropolitan Plan Making, (Reglonal Science Research Institute, Philadelphia), 1970.

13. Boyce, D.E. et. a1. "Specification of Plan Making Procedures for a Given Planning Situation," Highway Research Record, 394, 1972, 19-32.

14. Carpenter, R.D. Zoning Fundamenta1s: A Bibliography of Selected References, Exchange Bibliography, No. 495, (Council of Planning Librarians, Monticello, Illinois), 1973 . 
15. Carro11, M.A. An Exploration of the Relationship Between Urban Planning and Human Behavior: Toward the Identification of Professional Responsibilities, Exchange Bibliography, No. 60, (Council of Planning Librarians, Monticello, Illinois), 1968.

16. Chadwick, G.F. A Systems View of Planning; Towards a Theory of the Urban and Regional Planning Process, (Pergamon, Oxford), 1971.

17. Crecine, J.P. Governmental Problem Solving, (Rand McNally, Chícago), 1968.

18. Eulan, H. "The Informal Organization of Decisional Structures in Sma11 Legislative Bodies," Midwest Journal of Political Science, 13, 1969, 341-366.

19. Faludi, A. "Towards a Three-Dimensional Model of Planning Behavior," Environment and Planning, 3, 1971, 253-266.

20. Friend, J.K. and J.M.H. Hunter. 'Multi-Organisational Decision Processes in the Planned Expansion of Towns," Environment and Planning, 2, 1970, $33-54$.

21. Goodman, W.I. Planning Legislation and Administration, Exchange Bibliography, No. 57, (Council of Planning Librarians, Monticello, Illinois), 1968.

22. Heikoff, J.M. Urban Politics: Selected Readings Related to Planning, Exchange Bibliography, No. 177, (Council of Planning Librarians, Monticello, Illinois), 1971.

23. Jennings, M. K. "Public Administrators and Community Decision Making," Administrative Science Quarterly, 8, 1963, 18-43.

24. Kuk1inski, A.R. "Regiona1 Development, Regional Policies, and Regiona1 Planning; Problems and Issues," Regional Studies, 4, 1970, 269-278.

25. Kracht, J.B. The Application of Mode1s to the Planning Process with Special Emphasis on Land Use, Exchange Bibliography, No. 194, (Council of Planning Librarians, Monticello, Illinois), 1971.

26. Lenz, D.W. A Selected Bibliography on Planned Change and Community Planning Practice: Making Things Happen, Exchange Bibliography, No. 224, (Council of Planning Librarians, Montice11o, Illinois), 1971.

27. Levin, M.R. Community and Regional Planning: Issues in Public Policy, (Praeger, New York), 1972.

28. Mazziotti, D.F. Urban Design as a Subject of the Police Power: A Bibliography of Selected References, Exchange Bibliography, No. 205, (Council of Planning Librarians, Monticello, Illinois), 1971.

29. Meyer, M.W. Bureaucratic Structure and Authority; Coordination and Control in 254 Government Agencies, (Harper and Row, New York), 1972.

30. Mumphrey, A.J., J.E. Seley and J. Wolpert. "Decision Model for Locating Controversial Facilities," Journal of American Institute of Planners, 37, $1971,397-402$. 
31. Newe11, C. A Tentative Model of Political Threat and Administrative Decision-making Style, Unpublished Ph.D. dissertation, University of Texas at Austin, 1968.

32. Pickard, J.P. Taxation and Land Use in Metropolitan and Urban America, (Urban Land Institute, Washington), 1966.

33. Pidot, G.B. "A Principal Components Analysis of the Determinants of Local Government Fiscal Patterns," Review of Economics and Statistics, $51,1969,176-188$.

34. Presthus, R.V. Behavioral Approaches to Public Administration, (University of Alabama Press, University, Alabama), 1965.

35. Salih, K. "Judicial Relief and Differential Provision of Public Goods: A Case Analysis and Certain Prescriptions," Research on Conflict in Locational Decisions, Discussion Paper $\mathrm{XX}_{2}$ (Department of Regional Science, University of Pennsylvania, Philadelphia), 1972.

36. Schaller, H.G., ed. Public Expenditure Decisions in the Urban Community, (John Hopkins Press, Baltimore), 1963.

37. Stoots, C.F. Interlocal Cooperation: A Selected Bibliography, Exchange Bibliography, No. 103, (Council of Planning Librarians, Monticello, Illinois), 1969.

38. Systemetrics. A Framework for Federal Policies and Programs Concerning Urban Problems, (United States Department of Conmerce, Washington), 1969 .

39. Wilson, A.G. "Forecasting Planning," Urban Studies, 6, 1969, 347-367.

40. Wolpert, J. and D. Zillmann. "The Sequential Expansion of a Decision Model in a Spatial Context," Environment and Planning, 1, 1969, 91-104.

41. Zeitlin, M. Guide to the Literature of Cities: Abstracts and Bibliography, Part X: City Planning -- Theory and Practice, Exchange Bibliography, No. 314-315, (Council of Planning Librarians, Monticello, Illinois), 1972. 


\subsection{Urban Transportation Policy-Making: General}

\subsubsection{Administration}

1. Bailey, J.A. Development of Regiona1 Transportation Policies: An Analysis of the Political Process With Emphasis on Decisions, Ph.D. dissertation, University of Pennsylvania, Philadelphia, 1966.

2. Braman, J.D., Jr. "The View From City Ha11," in J.D. Lewis, ed., Industrial Approaches to Urban Problems, (Praeger, New York), 1972, 83-93.

3. Burns, R.M. "Legislative, Institutional and Administrative Aspects of Urban Transportation," in Proceedings of the Canadian Urban Transportation Conference, 1st, $1969,237-271$.

4. Colcord, F.C., Jr. "Decision-Making and Transportation Policy: A Comparative Analysis," Southwestern Soc1al Science Quarterly, 47, 1967, 383-397.

5. Colcord, F.C., Jr. Urban Transportation Decision Making, Pt, 2, Houston: A Case Study, (Massachusetts Institute of Technology, Urban Systems Laboratory, Cambridge), 1970.

6. Colcord, F.C., Jr. Urban Transportation Decision Making, Pt. 3, The San Francisco Case Study, (Massachusetts Institute of Technology, Urban Systems Laboratory, Cambridge), 1971.

7. Dickey, J.W. and R.C. Stuart. "Implementation of Urban Transportation Decisions: A Simultaneous Category Mode1," Highway Research Record, 348, $1971,16-34$.

8. Doig, J.W. Metropolitan Transportation, Politics, and the New York Region, (Columbia University Press, New York), 1966.

9. Fitch, L.C, et. a1. Urban Transportation and Public Policy, (Chandler, San Francisco), 1964.

10. Hal11n, R.R. The Tri-State Transportation Commission: A Capability Analysis of a Metropolitan Policy Sub-System, Ph.D. dissertation, Columbia University, New York, 1969.

11. Illinois Governor's Task Force on Public Transportation in Northeastern Illinois. Legislative Analysis: Regional Transportation Agency Statutes and Proposals, (Governor's Task Force on Public Transportation, Springfield, Illinois), 1973. 
12. Joyner, H.R. "Regional-Local Conflicts in Transportation Planning," Transportation Engineering Journa1, 98, 1972, 515-519.

13. Lawrence, D.G. The Politics of Innovation in Urban Mass Transportation Policymaking: The New Systems Example, (United States Urban Mass Transportation Administration, Washington), 1970.

14. Mann, D. "Metropolitan Politics and Urban Transportation," in D. Mann, Systems Analysis of Urban Transportation, Vo1.4, (General Research Corporation, Santa Barbara, Ca1ifornia), 1968, 235-267.

15. Mayer, H.M. "Government Roles in City and Metropolitan Planning...in Relation to Transportation Planning," in Brotherhood of Railroad Trainmen, the report of the Conference on Mass Transportation, Cleveland, 1968, 227-241.

16. New York State Legislature. Preliminary Data Report of the Committee on Affairs of the City of New York on the Role of Public Authorities in Mass Transportation and Other Matters in the City of New York, (Conmittee of Affairs, Albany, New York), 1965.

17. RTKI and Peat, Marwick, Mitche11 and Company. Macro Transportation Impact Model Study, ( RTKL and Peat, Marwick, Mitchel1 and Company, Baltimore), 1970 .

18. United States Federal Highway Administration. Urbanized Area Transportation Planning Programs: Directory, (Office of Highway Planning, Urban Planning Division, Washington), 1971.

19. United States Urban Mass Transportation Administration. An Urban Transportation Bibliography, (United States Urban Mass Transportation Administration, Washington), 1971.

20. Webber, M.M. and S, Angel. "The Social Context for Transportation Policy," Science and Technology and the Cities, (Government Printing Office, Washington ), 1969. 


\subsubsection{Planning}

1. Applied Decision Systems. The Transportation Planning Laboratory, (Applied Decision Systems, Wellesley Hills, Massachusetts), 1972.

2. Bateman, J.R. and J.W. Brown. "Urban Planning, Transport, and Human Behavioral Science," in Barton-Aschman Associates, Guidelines for New Systems of Urban Transportation, (Barton-Aschman Associates, Chicago), Vo1.2, $1968,1-41$.

3. Bovy, P.H.L. and G.R.M. Jansen. Spatial Abstraction in Transportation Planning: A Preliminary Classified Bibliography, (Technische Hoge-School Institute for Town Planning Research, Delft), 1971.

4. Boyce, D.E. "Toward a Framework for Defining and Applying Urban Indicators in Plan-Making," Urban Affairs Quarterly, 6, 1970, 145-171.

5. Boyce, D.E. "Specification of Plan-Making Procedures for a Given Planning Situation," Highway Research Record, 394, 1972, 19-32.

6. Boyce, D.E. and N.D. Day, assistance of C. McDonald. Metropolitan Plan Evaluation Methodology, (University of Pennsylvania, Institute for Environmental Studies, Philadelphia), 1969.

7. Boyce, D.E., N.D. Day and C. McDonald. Metropolitan Plan Making: An Analysis of Experience with the Preparation and Evaluation of Alternative Land Use and Transportation Plans, (Regional Science Research Institute, Philadelphia), 1970.

8. Branch, M.C. Transportation Developments, Cities, and Planning, (American Society of Planning Officials, Chicago), 1965.

9. Brand, D., et. a1. "Evaluation of Alternatives in Transportation Planning," Management Contro1s,13, 1967, 283-289.

10. Catanese, A.J., ed. New Perspectives in Urban Transportation Research, (Lexington Books, Lexington, Massachusetts), 1972.

11. Coblentz, H.S. "Transportation Planning and Social Issues: Function and Dysfunction," for Presentation at Institut fur Verkehrswesen, Universitat Karlsruhe, Karls ruhe, 1971.

12. Cole, L.M., ed. Tomorrow's Transportation; New Systems for the Urban Future, (United States Urban Transportation Administration, Washington), 1968.

13. Creighton, R.L. Urban Transportation Planning, (University of Illinois Press, Urbana), 1970. 
14. Dickey, J.W. and R.A. Ha11. Experiments With an Interactive Search Procedure for Changing Transportation to Guide Urban Growth, (Virginia Polytechnic Institute and State University Civil Engineering Department, B1acksburg, Virginia), 1971.

15. Domeneich, D.A. et. a1. Free Transit, (Lexington Books, Lexington, Massachusetts), 1971 .

16. Haefner, L.E. A Bibliography of Urban and Regiona1 Systems Analysis Mode1s, (Genera1 Motors Corporation Research Laboratories, Warren, Michigan), 1972.

17. Hickok, B. Goals, Objectives and Values: Selected References Relating to National, State and Urban or Regional Areas Covering General and Transportation Aspects, Exchange Bibliography, No. 391, (Counci1 of Planning Librarians, Monticello, Illinois), 1973.

18. Highway Research Board. "Bibliography: Criteria and Methods for Developing Transportation System Alternatives, "Highway Research Record, 148, $1966,4-5$.

19. Highway Research Board. "Transportation Systems P1anning, 12 Reports," Highway Research Record, 293, 1969, entire issue.

20. Horton, F.E. "Behaviora1 Mode1s in Transportation Planning," Transportation Engineering Journa1, American Society of Civil Engineers, 98, 1972, 411-419.

21. Hutchinson, B.G. "Structuring Urban Transportation Planning Decisions: The Use of Statistical Decision Theory, "Environment and P1anning, 1, 1969, 209-220.

22. Hutchinson, B.G. "Structuring Urban Transportation P1anning Decisions: Available Socia1 Science Constructs," Environment and P1anning, 2, $1970,251-265$.

23. Khan, A.M. "Transport Policy Decision Analysis: A Decision-Theoretic Framework," Socio-Economic Planning Science, 5, 1971, 159-171.

24. Koike, H. Planning Urban Transportation Systems, A Mode1 for Generating Socia1ly Desirable Transportation Network Configurations, (Washington State University Urban Transportation Program, Seattle), 1970.

25. Lane, R., T.J. Powel1 and P.P. Smith. Analytical Transport Planning, (Duckwort, London), 1971.

26. Leibbrand, K. Transportation and Town Planning, translated by N. Seymour, (Massachusetts Institute of Technology Press, Cambridge), 1964.

27. Mittelbach, F.G. and M.I. Schneider. "Remote Sensing: With Special Reference to Urban and Regional Transportation," The Annals of Regiona1 Science, 5, 1971, 61-72. 
28. Murin, M.J. Mass Transit Policy Planning, (Lexington Books, Lexington, Massachusetts), 1972 .

29. de Neufville, R. and R.L. Keeney. "Mu1tiattribute Preference Analysis for Transportation Systems Evaluation," Transportation Research,7, 1973, $63-76$.

30. Ockert, W. Transportation and the Community, (Ba1timore Regiona1 P1anning Counci1, Ba1timore), 1970.

31. Organization for Economic and Community Development. Future Directions for Research in Urban Transportation, (Office for Economic and Community Development, Paris), 1969.

32. Smerk, G.M. Readings in Urban Transportation, (Indiana University Press, B1oomington), 1968 .

33. Tanner, J.C. "A Strategic Mode1 for Urban Transport Planning," in Proceedings of the Internationa1 Symposium on the Theory of Traffic F1ow and Transportation, (American E1sevier Publishing Company, New York), $1971,389-403$.

34. Wachs, M. "The Role of Citizen's Opinions in Urban Transportation P1anning," in American Society of Mechanical Engineers, Defining Transportation Requirements, (American Society of Mechanica1 Engineers, New York), 1969, 205-213.

35. Willis, D.E. Urban Mass Transportation: A Bibliography, (Department of Transportation, Library Services Division, Washington), 1971. 


\subsubsection{Public Opinion and Citizen Participation}

1. Burnett, P. "Decisions Processes and Innovations: A Transportation Example," Economic Geography, 1974, forthcoming.

2. Fellman, G. Field Work as an Appropriate Method for Evaluating Community Values in Regard to Transportation Planning, (Brandeis University, Department of Sociology, Wa1tham, Massachusetts), 1970.

3. Fielding, G.J. "Transport Impact Research: Problems of Location Decisions at the Community Leve1," The Annals of Regional Sclence, 4, 1970, 117126.

4. Haney, D.G. and G.E. Klein. "Community Values in Transport Network Evaluation," Transportation Engineering Journal, 98, 1972, 823-835.

5. Highway Research Board. "The Community," Highway Research Record, 238, $1968,123-158$.

6. Highway Research Board. Community Values, Airlie House, 1969, Transportation and Community Values, Report, (Highway Research Board, National Research Council, Washington), 1969.

7. Hoinville, G. "Evaluating Community Preferences, " Environment and Planning, $1,1971,33-50$.

8. Passonneau, J.R. "Neighborhood Objectives as Generators of Regional Transportation Networks," Journal of the Urban Planning and Development Division, $99,1973,217-233$.

9. Regional Planning Commission for Jefferson, Orleans, and St. Bernard Parishes. Citizen Participation in Regional Transportation Planning: A Sunmary of the Macro Transportation Impact Model Study, (Regional Planning Commission for Jefferson, Orleans, and St. Bernard Parishes, New Orleans), 1971.

10. Reno, A.T., Jr. "Interaction Procedures in the Transportation Systems Planning Process," Highway Research Record, 394, 1972, 1-10.

11. Shaffer, J.H. Transportation and Community Values, (United States Federal Aviation Administration, Washington), 1971.

12. Travis, K.M. and S.C. Plog. "Conmunity Involvement in Transportation Planning: A New Approach," Highway Research Record, 380, 1972, 8-13.

13. Wachs, M. Evaluation of Engineering Projects Using Perceptions of and Preferences for Project Characteristics, (Transportation Center Research Report, Evanston, Il11nois), 1967. 
14. Wachs, M. "A Survey of Citizens' Opinions of the Effectiveness, Needs, and Techniques of Urban Transportation Planning, " Highway Research Record, $229,1968,65-76$.

15. Wachs, M. "Basic Approaches to the Measurement of Community Values," Highway Research Record, 305, 1970, 88-98.

16. Webber, M.M. "A1ternative Styles for Citizen Participation in Transport Planning," Highway Research Record, 356, 1971, 6-11. 


\subsubsection{Economic Effects}

1. Gauthier, H.L. "Geography, Transportation, and Regiona1 Development," Economic Geography, 46, 1970, 612-619.

2. Gladstone, R. and Associates, and A.M. Voorhees and Associates. Economic and Transportation Impact Analysis: Takoma Park Study Area, (Metropolitan Washington Council of Governments, Washington), 1968.

3. Kraft, G., J.R. Meyer and J.P. Valette. The Role of Transportation in Regiona1 Economic Development, (Lexington Books, Lexington, Massachusetts), 1971 .

4. Lock1in, D.P. Economics of Transportation, (R.D. Irwin, Homewood, I11inois), 1972 .

5. Mumphrey, A.J., Jr., J.E. Seley, and J. Wolpert. "A Decision Model for Locating Controversial Facilities," Journal of the American Institute of Planners, 37, 1971, 397-402.

6. Rasmussen, D.W. Joint Development: An Economic Input, (Florida State University, Transportation Center, Tallahassee, Florida), 1970.

7. Straszheim, M.R. "Researching the Role of Transportation in Regional Development," Land Economics, 48, 1972, 212-219.

8. Swoboda, R.A. Socio-Economic Implications of Urban Transportation, A Systems Ana1ysis: Case Study, Stuttgart, Germany, (Institut fur Stadtebau and Raumordnung, Stuttgart), 1968. 


\subsubsection{Social Effects}

1. Beshers, J.M. "Some Implications of Race and of Child Raising for Transportation Policy," in New York Academy of Sciences, Transportation: A Service..., (New York Academy of Sciences, New York), 1968, 189-194.

2. Carp, F.M. "Transportation and Retirement," Transportation Engineering Journal, 98, 1972, 787-798.

3. Coblentz, H.S. Transportation Planning and Social Issues: Function and Dysfunction, (Universitat Karlsruhe Institut fur Verkehrswesen, Kar1sruhe), 1971.

4. Cornehls, J. Urban Transportation: The Social Dimension - An Annotated Bibliography, Exchange Bibliography, No. 441, (Council of Planning Librarians, Monticello, Illinois), 1973.

5. Crain, J.L. Transportation Effects on the National Alliance of Businessmen Program, (Stanford Research Institute, Menlo Park, California), 1969.

6. Ellis, R. "Review of the Literature of Social Impacts of Transportation Policies," in Northwestern University Transportation Center, Strategies for the Evaluation of Alternative Transportation Plans, (Northwestern University Transportation Center, Evanston, Illinois), 2, 1967, 285-304.

7. Ellis, R.H. Toward Measurement of the Community Consequences of Urban Transportation Investment, Ph.D. dissertation, Department of Civil Engineering, Northwestern University, 1968.

8. E1lis, R.H. "Some Comments on Social Impacts and Urban Transportation Planning, " in Papers and Discussions of the 1968 Transportation Engineering Conference, New York, 1969, 276-285.

9. Homburger, W.S. "Fixed Facilities and Shifting Values," High Speed Ground Transportation Journa1, 4, 1970, 9-22.

10. Institute of Public Administration. Abstracts of Selected References on the Social Aspects of Urban Transportation, (United States Department of Mass Transit Administration, Washington), 1970.

11. Kain, J.F. and J.R. Meyer. "Transportation and Poverty," Public Interest, $1970,75-87$.

12. Morris, R.L. "Social Considerations of Urban Transportation Systems," Transportation Engineering Journal, 96, 1970, 333-339.

13. National Research Council, Highway Research Board. Transportation and Community Values: Report of a Conference Held at Warrenton, Virginia, March 2-5, (National Research Council, Highway Research Board, Washington), 1969. 
14. Swodoba, R.A. Socio-Economic Implications of Urban Transportation, A Systems Analysis: Case Study, Stuttgart, Germany, (Institut fur Stadtebav und Raumordnung, Stuttgart), 1968. 


\subsubsection{Effects on Land Use and Land Values}

1. Barden, R. and J.H. Thompson. The Urban Frontier, (Urban Transportation Institute, Syracuse University, Syracuse, New York), 1970.

2. Bourne, L.S. and M.J. Doucet. Dimensions of Metropolitan Physical Growth: Land Use Change, Metropolitan Toronto, (Centre for Urban and Coumunity Studies, Toronto University, Toronto), 1970.

3. Brand, D., B. Barber and M. Jacobs. "Technique for Relating Transportation Improvements and Urban Development Patterns," Highway Research Record, $207,1967,53-67$.

4. Goldberg, M.A. "Transportation, Urban Land Values, and Rents: A Synthesis," Land Economics, 46, 1970, 153-162.

5. Goldberg, M.A. Assessing the Impact of Transportation Improvements on Land Use, (Faculty of Commerce and Business Administration, University of British Columbia, Vancouver), 1970.

6. Hamburg, J.R., G.J.H. Brown, and M. Schneider. "Impact of Transportation Facilities on Land Development," Highway Research Record, 305, 1970, $172-178$.

7. Irwin, N.A. "Review of Existing Land-Use Forecasting Techniques," Highway Research Record No. 88, (Highway Research Board, Washington), 1965.

8. Lee, D.B., Jr. Bart Impact Studies Fina1 Report Series, (Institute of Urban and Regional Development, University of California, Berkeley, California), 1973.

9. Lee, D.B., Jr. "Requiem for Large-Scale Mode1s," Journal of the American Institute of Planners, 39, 1973, 163-178.

10. Lee, D.B., Jr. and C.P. Averons. "Land Use and Transportation: Basic Theory," Environment and P1anning, 5, 1973, 491-502.

11. Manks, H. and S. Spitz. A Review of Transportation Aspects of Land-Use Contro1, (Highway Research Board, Wash1ngton), 1966 .

12. National Center for Highway Research. "A Review of Transportation Aspects of Land-Use Control," National Cooperative Highway Research Program, Report No. $31,1966$.

13. Northwestern University Transportation Center. Land Use Models Developed in Urban Transportation Studies: Selected References; A Bibliography, (Northwestern University Transportation Center, Evanston, Illinois), 1967. 
14. Pollard, W.S. "Operations Research Approach to the Reciprocal Impact of Transportation and Land Use," Journal of the Urban P1anning and Development Division, American Society of Civil Engineers, 92, 1966, 21-33.

15. Prytula, G. Community Mobility Systems, (Urban Land Institute, Washington), 1970 .

16. Rice, S. "Transportation Economics in the Land-Use Developments of Cities," Traffic Quarter1y, 20, 1966, 393-404.

17. Traffic Research Corporation. Merseyside Area Land Use/Transportation Study: Miscellaneous Reports Including. A Review of the Application of Gaming Techniques to Planning, (Traffic Research Corporation, Liverpoo1), 1969.

18. Urban Land Research Analysts Corporation. Urban Land Value as it Relates to Policy, (Urban Land Research Analysts Corporation, Lexington, Massachusetts), 1969 .

19. Weiss, S.F. et. a1. "Land Value and Land Development Influence Factors: An Analytical Approach for Examining Policy Alternatives," Land Economics, $43,1966,230-233$.

20. Wendt, P.F. and M.A. Goldberg. "The Use of Land Development Simulation Models in Transportation Planning, " Highway Research Record, 285, 1969, 82-91.

21. Wheeler, J.0. Spatial Studies of Transportation: Introduction and Annotated Bibliography, Exchange Bibliography, No. 324-325, (Council of Planning Librarians, Montice11o, I11inois), 1972.

22. Zeitlin, M. Guide to the Literature of Cities: Abstracts and Bibliography, Part III: Urban Transportation, Exchange Bibliography No. 307, (Council of P1anning Librarians, Montice11o, I11inois), 1972. 


\subsubsection{Other Environmental Effects}

1. Eberhard, J.P. "An Analysis of the Impact of Transportation Systens on Other Systems of the City, " in Institute of Public Administration, Workshop on Transportation for New Towns and Communities, (Institute of Public Administration, New York), 1969, 74-99.

2. Metropolitan Toronto Transportation Plan Review. Strengths and Weaknesses of the Current Metropolitan Toronto Transportation System, Pt. 8 , (Metropolitan Toronto Transportation Plan Review, Toronto), 1973.

3. Weiner, P. Environmental Factors in Transportation Planning, (Lexington Books, Lexington, Massachusetts), 1972. 


\subsection{Airport Investment and Its Effects}

\subsubsection{Administration}

1. Allen, R. "Plans in Spite of Politics at Scotland's Busy Airports," Airport World, 2, 1969, 8-12.

2. Anonymous. "Computers Help Integrate Transportation at Dallas Airport," World Highways, $19,1968,4$.

3. Brown, D.A. "New York Airport Developments Keyed to Political Scene," Aviation Week, $91,1969,118-120$.

4. Bulban, E.J. "Dallas, Ft. Worth Approve Plan for Airport," Aviation Week, $89,1968,57-59$.

5. Neales, W.H.S. "Decision Making in Airport Planning and Design," in University of Toronto Centre for Urban and Community Studies, Readings in Airport Planning, (University of Toronto Centre for Urban and Community Studies, Toronto), 1972, 1-27.

6. Great Britain Board of Trade. The Third London Airport, Presented to Parliament by the President of the Board of Trade and the Minister of Housing and Local Government, May, 1967, (Her Majesty's Stationery Office, London), 1967.

7. Great Britain, Commission on the Third London Airport. Papers and Proceedings, Vo1. 1, Stage 1: Public Hearings, pt. 1, Written and Ora1 Evidence, a1so

Vo1. 2, Stage I: Public Hearings, pt. 2, Other Written Evidence,

Vo1. 7, Stage III: Research and Investigation - Assessment of Short-Ligted Sites,

Vo1. 8, pt. 2, Stage III : Research and Investigation - Specia11y Commissioned Studies,

Vol. 9, Stage III: Research and Investigation - Public Evidence, (Her Majesty's Stationery Office, London), 1969-1970.

8. Great Britain, Commission on the Third London Airport. Report, (Her Majesty's Stationery Office, London), 1971.

9. Keeney, R.L. "A Decision Analysis With Multiple Objectives: The Mexican City Airport," Be11 Journal of Economics and Management Science, 3, $1973,101-117$. 
10. Massachusetts Institute of Technology Civil Engineering Systems Laboratory. Use of Decision Analysis in Airport Development for Mexico City, (Massachusetts Institute of Technology Department of Civil Engineering, Cambridge), 1972 .

11. Ripley, R.B. "Congress Champions Aid to Airports," in F.N. Cleaveland et. a1., Congress and Urban Problems; A Casebook on the Legislative Process, (Brookings Institution, Washington), 1969, 20-71.

12. United States Congress Senate Committee on Commerce. Airport and Airways Development Act of 1969, Report, (91st Congress, Washington), 1969. 


\subsection{2a Planning - General}

1. Campbe11, H.S. et. a1. Alternative Development Strategies for Air Transportation in the New York Region, 1970-1980, (Rand Corporation, Santa Monica, California), 1969.

2. Campbe11, H.S., D.M. Landi and A.J. Rolfe. Systems for Air Transportation Serving the New York Metropolitan Area, 1975-1980, (Rand Corporation, Santa Monica, Ca1ifornia), 1969.

3. Cande1a, B. et. a1. A Conceptual Approach to Urban Airport Requirements in the 1980-2000 Time Frame, (Hudson Institute, Croton-on-Hudson, New York), 1968 .

4. Dade County, Florida, Metropolitan Planning Department. Airport Master Plan, (Dade County Metropolitan Planning Department, Miami), 1968.

5. Dallaire, G. "Dallas-Fort Worth: World's Largest, Best Planned Airport," Civi1 Engineering, 68, 1973, 53-58.

6. Dworkin, M.L. "Planning for Airports in Urban Environments - A Survey of the Problem and its Possible Solutions," Transportation Law Journal, 5, $1973,183-214$.

7. East-West Gateway Coordinating Council. Regional Evaluation of the Significance of Proposed Federal Assisted Project, (St. Louis Metropolitan Area Airport Authority, St. Louis, Missouri), 1971.

8. Forsyth, P.J. "The Timing of Investments in Airport Capacity; The Case of London," Journal of Transport Economics and Policy, 6, 1972, 51-68.

9. Hutchinson, B.G. "Structuring Urban Transportation Planning Decisions: Available Social Science Constructs," Environment and Planning, 2, 251-265, 209-220.

10. Keeney, R.L. "A Decision Analysis With Multiple Objectives; The Mexico City Airport," Be11 Journal of Economics and Management Science, 3, 1973, 101-117.

11. Khan, A.M. "Transport Policy Decision Analysis: A Decision Theoretic Framework," Soc1o-Economic Planning Science, 5, 1971, 159-171.

12. Kitchen, T. "The Generation and Coarse Evaluation of Alternatives in Regional Planning," Journal of the Royal Town Planning Institute, 58, 1972, $8-12$. 
13. Kling, V.G. and Associates. Washington National Airport; Master Plan Report, (Government Printing Office, Washington), 1968.

14. Landrum and Brown. A Study of the Air Transportation Potentials and Facility Requirements in the Metropolitan Boston Air Service Area 1970 Through 1990, (Landrum and Brown, Cincinnati), 1968.

15. Massachusetts Institute of Technology. Civil Engineering Systems Laboratory. Use of Decision Analysis in Airport Development for Mexico City, Massachusetts Institute of Technology, Cambridge), 1972 .

16. Massachusetts Institute of Technology, Flight Transportation Laboratory. The Urban Planning/Airport Planning Interface; A Basic Blbliography. (Massachusetts Institute of Technology, Cambridge), 1969.

17. Massachusetts Institute of Technology, Interdepartmental Student Project in Systems Engineering. Project BOSPORUS: Boston Airport and Seaport Utilization Study, Student Project in Special Studies in Systems Engineering, (Massachusetts Institute of Technology, Cambridge), 1968.

18. Monchaux, J. de. "Joint Planning of Air and Urban Systems," American Inst1tute of Aeronautics and Astronautics, 2, 1971, 43-52.

19. Neales, W.H.S. "Decisionmaking in Airport Planning and Design," in University of Toronto Centre for Urban and Community Studies, Readings in Airport Planning, ( University of Toronto, Toronto), 1972, 1-27.

20. Newman, H.L. "An Innovative Approach to Airport Planning," Journa1 of Air Law and Commerce, 39, 1973, 353-359.

21. Peat, Marwick, Livingston and Company. Report on Preliminary Plan for Capito1 Region, (Capital Region Planning Agency, Boston), 1969.

22. Prokosch, W. "Planning in the Dallas-Ft. Worth Regional Airport," Civil Engineering, 62, 1967, 50-53.

23. Pulling, R.W. "Some Problems in A1rport Planning for Large Cities," in American Association of State Highway Officlals, Proceedings, 1970 Convention, (American Association of State Highway Officials, Washington), 1970, 288322 .

24. Robins, P. "Airport Development: A Wor1d-Wide Survey," Aerospace, 5, 1967 , 4-12, $16-19$.

25. Southeastern Wisconsin Regional Planning Coumission. Comprehensive Regional Planning Program Prospectus, (Southeastern Wisconsin Regional Planning Commission, Waukesha, Wisconsin), 1969.

26. Standing Conference on London and South East Regiona1 Planning. Third London Airport; Joint Report by the Administrative and Technical Panels, (Her Majesty's Stationery Office, London), 1969.

27. Sud, I.K. Modeling of a Satellite Airport System for Large Metropolitan Areas: A Systems Analysis, Ph.D. dissertation, Department of Industria1 Engineering, Stanford University, 1971. 
28. Sullivan, T. "The Management Systems Approach to Airport Planning: Identifying and Overcoming Restraints," Journal of Air Law and Commerce, 36, 1970, 387-393.

29. Tippetts-Abbett-McCarthy-Stratton. Airport Master Plan: Dallas Fort Worth Regional Airport, (Tippetts-Abbett-McCarthy-Stratton, New York), 1967.

30. United Air Lines. Master Plan Report, Los Angeles International Airport, (United Air Lines, Chicago), 1967.

31. United States Federal Aviation Administration and Airport Operators Council International. Planning the Metropolitan Airport System, (Government Printing Office, Washington), 1970.

32. Wilsey and Ham. Regional Airports System Study, San Francisco Bay Region, Summary Report, Phase 1, (Bay Area Study of Aviation Requirements and the Association of Bay Area Governments, San Francisco), 1970. 


\subsection{2b Location Planning}

1. Armstrong, H.W. "A Network Analysis of Airport Accessibility in South Hampshire," Journal of Transportation Economics and Policy, 6, 1972 , 294-307.

2. Bambiger, M. and H. Vandersypen. Major Conmercial Airport Location: A Methodology for the Evaluation of Potential Sites, (Northwestern University Transportation Center, Evanston, Illinois), 1969.

3. Christian, R. "St. Louis Intercontinenta1: The Site Selection QuagmireLogic or Politics," Airport Wor1d, 5, 1972, 19-21.

4. Doganis, R.S. "Airport Location - The Factors Involved," in Institute of Civil Engineers, World Airports: The Way Ahead, (Institute of Civil Engineers, London), 1970, 72-76.

5. Goldstein, S. "Aircraft Noise and the Selection of Airport Sites," Pennsylvania Bar Association Quarter1y, 43, 1972, 229-237.

6. Great Britain, Commission on Third Lond on Airport. Papers and Proceedings, Vo1. 7, Stage III: Research and Investigation - Assessment of Short1isted Sites, (Her Majesty's Stationery Office, London), 1970.

7. Great Britain, Cormission on the Third London Airport. Papers and Proceedings, Vo1. 8, pt. 2, Stage III : Research and Investigation - Specially Cormissioned Studies, (Her Majesty's Stationery OEice, London), 1970.

8. Harper, D.V. "The Airport Location Problem: The Case of Minneapolis St. Pau1," ICC Practitioner's Journa1, 38, 1971, 550-582.

9. Have1, R.E. Location Theory and a Third Chicago Airport, (Northwestern University Graduate School of Business Administration, Chicago), 1967.

10. Institute of Civil Engineers and Royal Institute of British Architects. Problems Involved in the Development and Siting of Airports, (Institut du Transport Aerien, Paris), 1970.

11. Landrum and Brown and Real Estate Research Corporation and Airborne Instruments Laboratory. Chicago Airport Site Selection Study: First Memorandum Report, (Landrum and Brown, Real Estate Research Corporation and Airborne Instruments Laboratory, Cincinnati), 1967.

12. Lochner, H.W. A Preliminary Analysis of a Green Garden Township Site for an International Airport Serving the Chicago Region, (South Suburban A1rport Committee, Chicago), 1968 . 
13. Mishan, E.J. "What is Wrong With Roskill?" Journal of Transportation Economics and Policy, 4, 1970, 221-234.

14. de Neufville, R. and R. L. Keeney. "Multiattribute Preference Analysis for Transportation Systems Evaluation," Transportation Research, 7, 1973, 6376 .

15. O'Doherty, J.D. A Location Study for a System of V/STOL Airports in the Boston Metropolitan Area, (Massachusetts Institute of Technology, Flight Transportation Laboratory, Cambridge), 1966.

16. Pak-Poy, P.G. "Airport Location," in P.G. Pak-Poy and Associates, Traffic, Planning and Research; Aviation Systems Planning, (P.G. Pak-Poy and Associates, Adelaide), 1970.

17. Real Estate Research Corporation. Chicago Airport Site Selection Study; An Analysis of Some of the Major Considerations, (Real Estate Research Corporation, Chicago), 1968.

18. Sealy, K.R. "The Siting and Development of British Airports," Geographical Journa 1, 133, 1967, 148-177.

19. Sklar, B. "Airport Access Criteria as a Basis for Locating VTOL, STOL and Conventional Airports," in American Society of Mechanical Engineers, Defining Transportation Requirements, (American Society of Mechanical Engineers, New York), 1969, 153-165.

20. Somerset County, New Jersey Planning Board. A Report on the Proposed Jetport, (Somerset County Planning Board, Somerville, New Jersey), 1967.

21. Standing Conference on London and South East Regional Planning. Third London Airport; Joint Report by the Administrative and Technical Panals, (Her Majesty's Stationery Office, London), 1969.

22. Traffic Research Corporation. Merseyside Area Land Use/ Transportation Study: Miscellaneous Reports Including a Review of the Application of Gaming Techniques to Planning, (Traffic Research Corporation, Liverpoo1), 1969 .

23. United States Federal Aviation Administration. Airport Site Selection, (Government Printing Office, Washington), 1967.

24. United States Federal Aviation Administration National Aviation Facilities Experimental Center. Graphic Simulation Study of Sites for a Third Chicago Metropolitan Airport, (Systems Research and Development Service, Atlantic City, New Jersey), 1968.

25. United States Federal Aviation Administration National Aviation Facilities Experimental Center. Graphic Simulation Study of Two Sites for a Second Major Airport in the Atlanta Area: Final Report, (Systems Research and Development Service, Atlantic City, New Jersey), 1970.

26. United States Federal Aviation Administration. Simulation Study of Two Sites for a Third Chicago Metropolitan Airport: Final Report, (United States Department of Transportation, Washington), 1970. 


\subsubsection{Public Opinion}

1. Adams, R.B. and S.R. Dickson. "Airport Location: Criteria and Conflict," The Iowa Geographer, 31, 1973.

2. Anonymous. "Choice of Stansted Sparks Controversy," Aviation Week, 86, 1967,30 .

3. Anonymous. "New York Jetport Battle Heats Up," Business Week, 1969, 72.

4. Anonymous. "Program 70's: A Decade of Progress," Airport World, 5, 1972, 24-27.

5. Association of Bay Area Governments. Regional Airport Systems Study Public Hearing, Fairfield, California, (Association of Bay Area Governments, Berkeley, California), 1971.

6. Becker Research Corporation. Attitudes of Logan Airport Abutters Toward the Airport, Noise, Expansion and Selling Their Homes, (Becker Research Corporation, Boston), 1971 .

7. Berge, S. Airports, Aesthetics and Environment: Should We or Should We Not Build A New Airport in Lake Michigan? , (Northwestern University Graduate School of Management, Evanston, Illinois), 1970.

8. Berger, M.M. "Nobody Loves an Airport," Southern California Law Review, $42,1970,631-789$.

9. CLM/Systems, Incorporated. Airports and Their Environment, (Government Printing Office, Washington), 1972 .

10. Carter, J.W. "N.Y. Jetport Still Becalmed Amid Debate," Aviation Week, $90,1969,28-29$.

11. Coleman, H.J. "Political Backfires Blocking New Airport for London," Aviation Week, 91, 1969, 130-131.

12. Cook, 0. The Stansted Affair; A Case for the People, (Pan Books, London), 1967 .

13. Cove11, M. and Partners. The Third London Airport: Foulness, (Noise Abatement Society, London), 1967.

14. Great Britain, Commission on the Third London Airport. Papers and Proceedings, Vol. 1 Stage I: Public Hearings, pt. 1, Written and Oral Evidence, (Her Majesty's Stationery Office, London), 1969. 
15. Great Britain, Comission on the Third London Airport. Papers and Proceedings, Vo1. 2 Stage I: Public Hearings, pt. 2, Other Written Evidence, (Her Majesty's Stationery Office, London), 1969.

16. Great Britain, Commission on the Third London Airport. Papers and Proceedings, Vol. 9, Stage III: Research and Investigation - Public Evidence, (Her Majesty's Stationery Office, London), 1970.

17. Great Britain, Ministry of Housing and Local Government. Report of Inquiry into the Local Objections to the Proposed Development of Land at Stansted as the Third Airport for London, (Her Majesty's Stationery Office, London), 1967.

18. Hildred, W. "Hildred on Stansted," Aerospace, 5, 1967, 12-14.

19. Keeney, R.L. "A Decision Analysis With Multiple Objectives: The Mexico City Airport," Bell Journal of Economics and Management Science, 4, $1973,101-117$.

20. Lantner, G.H. Cormunity Opposition to Airport Development, (Massachusetts Institute of Technology, Department of Civil Engineering, Cambridge), 1972.

21. Massachusetts Institute of Technology, Civil Engineering Systems Laboratory. Use of Decision Analysis in Airport Development for Mexico City, (Massachusetts Institute of Technology, Department of Civil Engineering, Cambridge), 1972.

22. Mays, C., A. Corkill and J. Seddon. "When Somebody Says Jetport, The Public Says Ouch: A Report on the Orange County Impact Hearing in New York," Land scape Architecture, V, 1973, 276-278.

23. Mishan, E.J. "What is Wrong with Roski11?," Journal of Transportation Economics and Policy, 4, 1970, 221-234.

24. Nwaneri, V.C. "Equity in Cost-Benefit Analysis; A Case Study of the Third London Airport," Journal of Transportation Economics and Policy, $4,1970,235-254$.

25. Shaffer, J.H. Transportation and Community Values, (Government Printing Office, Washington), 1971.

26. Stratford, A. and Associates, eds. Studies of the Site for a Third London Airport, (North West Essex and East Herts Preservation Association, Maidenhead, England), 1966.

27. Wise, G.E. "Ontario Internationa1; Los Angeles Satellite Absorbs Booming Growth While Retaining Community Support," Airport World, 6, 1973, 10-12. 


\subsubsection{Economic Effects}

1. Bean, G.J."Area Survey of Airport Environs Economic Reactions Present and Future," Society of Automotive Engineers Proceedings, $1972,17-24$.

2. Beinhaker, P. and A. Elek. 'Methods for Evaluating Transportation Investment: Montreal Airport Study," in Proceedings of the Twelfth Annual Meeting, Transportation Research Forum, (Richard B. Cross, Oxford, Indiana), 1971, 55-66.

3. CLM/Systems, Incorporated. Airports and Their Environment, (Government Printing Office, Washington), 1972.

4. Chevalier, M. "Regional Development Impact of Major Transportation Investment, Ste. Scholastique, "in Transportation Research Forum, Proceedings, Twelfth Annual Meeting, (Richard B. Cross, Oxford, Indiana), 1971, 89-98.

5. Consad Research Corporation. A Community/Airport Economic Development Mode1: Final Report, (Consad Research Corporation, Pittsburgh), 1972.

6. Dean, E.E. "Construction Economics and Community Impact," in Society of Automotive Engineers Air Transportation Conference, (Society of Automotive Engineers, New York), 1972, 1-9.

7. Downes, W.E. "O'Hare International Airport: What it Means to Chicago," in Society of Automotive Engineers Air Transportation Conference, (Society of Automotive Engineers, Washington), 1972.

8. Downey, J.D. "Economics of a New Regional Airport," American Society of Civil Engineers Conference Proceedings, 1972, 57-71.

9. Foster, J.A. "The Airport - A Center of Economic Gravity," Society of Automotive Engineers Proceedings, 1972, 41-48.

10. Hal1, P.G. "Regional Planning and Airport Location," in World Airports: The Way Ahead, (Institute of Civil Engineers, Lond on), 1970, 77-82.

11. Higgins, B. "The Montreal Airport Site: The Spatial Multiplier and Other Factors Affecting its Selection," Growth and Change, 2, 1971.

12. Howard, G. "The Airport Environment-Economic Impact on the Community," Society of Automotive Engineers Proceedings, 1972, 10-16.

13. Isard, W. "Location Games With Application to Classic Location Problems," in W. Isard, General Theory, (Massachusetts Institute of Technology Press, Cambridge), $1969,430-490$. 
14. Institute of Transportation and Traffic Engineering. Airport Economics and Finance: Proceedings of a Seminar Presented by University of California and the University of California Extension for the Air Transport Association of America, (University of California, Berkeley), 1967.

15. Jerome, A. and J. Nathanson. "Socioeconomic Implications of Airport Planning, " Traffic Quarterly, 25, 1971, 267-286.

16. Jodeau, J. Air Transport and Regiona1 Economics, (Institut du Transport Aerien, Paris), 1969 .

17. Likens, J.D. The Welfare Costs of Non-Optimal Airport Utilization: A Case Study of the Washington-Baltimore Airports, Ph.D. dissertation, University of Minnesota, Minneapolis, 1970.

18. Martin, J.N. "Economic Impact of Airport Investment and Use in North Carolina," Transportation Journa1, 11, 1972, 46-52.

19. Meenan, D.C. Airport Economics; Its Application to the New Airports for the 70's, (Society of Automotive Engineers, New York), 1967.

20. Metropolitan Washington Council of Governments. Air Travel Demand in the Washington-Baltimore Region 1970-1990: A Summary Report, (Metropolitan Washington Council of Governments, Washington), 1968.

21. Nammack, J.A. "Airports and Their Economic Impact," Airport Service Management, $11,1971,24-25$.

22. Neufville, de. R. and T. Yajima. "Economic Impact of Airport Development," in Proceedings of the Twelfth Annual Meeting of Transportation Research Forum, (Richard B. Cross, Oxford, Indiana), 1971, 123-133.

23. Northwestern University, Transportation Center Library. The Economic Impact of Airports in the United States, (Northwestern University Transportation Center Library, Evanston, Illinois), 1968.

24. Nwaneri, V.C. "Equity in Cost Benefit Analysis; A Case Study of the Third London Airport," Journal of Transportation Economics and Policy, 4, 1970, 235-254.

25. Paik, L.K. The Effect of Aircraft Noise on the Value of Residential Property Near Three Selected Airports, (Consortium of Universities, Urban Transportation Center, Washington), 1972 .

26. Regional Science Research Institute. Economic Impact of the Dallas-Fort Worth Regional Airport on the North Central Texas Regions in 1975, (Regional Science Research Institute, Philadelphia), 1970.

27. Regiona1 Science Research Institute. Future Structure of the North Central Texas Region, (North Central Texas Council of Governments, Arlington, Texas), 1970 .

28. Regiona1 Science Research Institute. Relative Economic Effects on Penjerdel of Two Alternative Jetport Proposals in New Jersey, (Regional Science Research Institute, Philadelphia), 1969. 
29. Ruppentha1, K.M. "The Direct Impact of Ports and Airports on Industria1 Development," in University of British Columbia, Faculty of Commerce and Business Administration, Colloquium on Investment Planning for Ports and Airports, (University of British Columbia, Vancouver), 1970.

30. Ruppentha1, K.M. "Some Socioeconomic Cunsiderations," in K.M. Ruppentha1, ed., Air Transportation - A Forward Look, (Stanford University, Graduate Schoo1 of Business, Stanford, California), 1970.

31. Texas Aeronautics Commission. Importance of a Modern Airport, (Texas Aeronautics Commission, Austin, Texas), 1965.

32. United States Department of Transportation, Federa1 Aviation Administration, Systems Planning Division, Airports Service. The Airport - Its Influence on the Community Economy, (Government Printing Office, Washington), 1967 .

33. Wheat, L.E. The Effect of Airline Service on Urban Manufacturing Growth, (Economic Development Administration, Washington), 1969. 


\subsubsection{Social Effects}

1. CLM/Systems Incorporated. Airports and Their Environment, (Government Printing Office, Washington), 1972.

2. Greenfield, S.S. "The Airport and the Community," Public Works, 102 , $1971,76-79$.

3. Ha11, P.G. "Regional Planning and Airport Location," in Institute of Civil Engineers, World Airports: The Way Ahead, (Institute of Civil Engineers, London), 1970, 77-82.

4. Jerome, A. and J. Nathanson. "Socioeconomic Implications of Airport P1anning," Traffic Quarterly, 25, 1971, 267-286.

5. Ruppentha1, K.M. "Some Socioeconomic Conisderations," in K.M. Ruppentha1, ed., Air Transportation - A Forward Look, (Stanford University, Graduate School of Business, Stanford, Ca1ifornia), 1970, 153-160.

6. Urban Systems Research and Engineering, Incorporated. Community Values in the Planning and Evaluation of Airport Development Projects, (National Technical Information Service, Washington), 1972. 


\subsubsection{Effects on Land Use and Land Values}

1. Air Transport Association of America, Economics and Finance Department. Excerpts of Information on Land Values Around Airports, (Air Transport Association of America, Washington), n.d.

2. Anonymous, "Airport Area Housing Criticized," Aviation Week, 87, 1967, 55-57.

3. Anonymous. "The Land Boon at a Texas Airport," Business Week, 1972, 116117 .

4. Arde, and Town and City, Incorporated. A Study of the Optimum Use of Land Exposed to Aircraft Landing and Takeoff Noise, (United States Nationa1 Aeronautics and Space Administration, Washington), 1966.

5. Bennett, G.R. Industria1 Air Park: Methods of Development, Master's Thesis, University of Ok1ahoma, Norman, 1965.

6. Bovay, H.E. "Land Use Plan for Houston's Intercontinental Airport," Journal of the Urban Planning and Development Division, American Society of Civil Engineers, 93, 1967, 57-73.

7. British Airports Authority. Gatwick Airport - Draft Land Use P1an: Explanatory Note, (British Airports Authority, London), 1970.

8. CLM/ Systems, Incorporated. Airports and Their Environment, (Government Printing Office, Washington), 1972 .

9. California Legislature, Assembly, Conmittee on Comerce and Public Utilities. Airport Zoning, (Committee on Commerce and Public Utilities, Sacramento, California), 1969.

10. Consad Research Corporation. A Community/Airport Economic Development Mode1: Final Report, (Consad Research Corporation, Pittsburgh), 1972.

11. Cripps, E.L. and D.H.S. Foot. "The Urbanization Effects of a Third London Airport," Environment and P1anning, 2, 1970, 153-192.

12. Crowley, R.W. A Case Study of the Effects of an Airport on Land Values," (Queen's Printer, Ottawa), 1972.

13. Crowley, R.W. "A Case Study of the Effects of an Airport on Land Values," Journa1 of Transport Economics and Policy, 7, 1973.

14. Edwards, G. "Jumbo Jets and the Energing Airport City," Planning 1967, (American Society of Planning Officials, Chicago), 1967. 
15. Fisher, L. "Airport Industry Parks, Who Should Develop Them?" Urban Land, $25,1966,3-6$.

16. Foster, J.A. "The Airport: A Community Asset," Appraisa1 Journa1, 37, 1969, 543-554.

17. Great Britain Board of Trade. The Third London Airport, Presented to Parliament by the President of the Board of Trade and the Minister of Housing and Loca1 Government, (Her Majesty's Stationery Office, London), 1967.

18. Ha11, P.G. "Regional Planning and Airport Location," in Institute of Civil Engineers, World Airports: The Way Ahead, (Institute of Civil Engineers, London), 1970, 77-82.

19. Hanten, E. A Method of Measuring A1rport Influence and Determining Its Effect on Land Values and Land Use - Greater Pittsburgh as an Example, Ph.D. dissertation, University of Pittsburgh, 1962 .

20. I11inois Department of Aeronautics. Zoning Regulations for ChicagoO'Hare International Airport, (Department of Aeronautics, Springfield), 1965.

21. Kaplinsky, A.S. "Airports - Flight Paths - Police Power v. Eminent Domain," Journal of Air Law and Commerce, 35, 1969, 635-645.

22. Liston, L. "The Case for the Airport New Town," Industrial Development and Manufacturers Record, 38, 1969, 3-9.

23. Malden, J. A Selected Bibliography on Airport Zoning, (Municipal Reference Library, (hicago), 1963.

24. Martin, W.H. "Aviation - Economic Impact on Rea1 Estate," Appraisal Jour$\underline{\text { na1 }}, 40,1972,231-234$.

25. McArthur, N.M. Airport and Community: 5 Case Studies of Local Airport Land Use, (Queen's Printer, Ottawa), 1965.

26. Morgan, C. Airports: Land Use, Zoning, and Property Rights, (Municipa1 Reference Library, Chicago), 1969.

27. New Jersey Department of Conservation and Economic Development. Air Facilities and the Land Use Pattern in New Jersey, (New Jersey Department of Conservation and Economic Development, Trenton), 1965.

28. Riggs, H.L., Jr. "Airport Zoning - A Sleeping Giant," Airport Wor1d, $6,1973,32-34$.

29. United States Department of Transportation, Federal Aviation Administration. Aids Available for Compatible Land Use Planning Around Airports, (clearinghouse, Springfield, Virginia), 1966 .

30. United States Department of Transportation, Federal Aviation Administration. Mode1 Airport Zoning Ordinance, (Government Printing Office, Washington), 1967. 
31. United States Department of Transportation, Federal Aviation Administration. Compatible Land Use Planning on and Around Airports, (Clearinghouse, Springfield, Virginia), 1966.

32. United States Federal Aviation Agency. Planning the Airport Industrial Park, (United States Federal Aviation Agency, Washington), 1965.

33. United States Department of Housing and Urban Development, Office of Metropolitan Planning and Development, Office of Planning Assistance and Standards, Airport Environs: Land Use Controls, (Housing and Urban Development, Washington), 1970.

34. United States Federal Aviation Administration. Model Airport Hazard Zoning Ordinance, (Government Printing Office, Washington), 1972.

35. Urban Systems Research and Engineering. Land Use Contro1 Strategies for Airport Impact Areas: Final Report, (Urban Systems Research and Engineering, Cambridge, Massachusetts), 1972.

36. Walther, H.0. "Land Values Near Airports," in Institute of Civil Engineers, World Airports: The Way Ahead, (Institute of Civil Engineers, London), $1970,102-106$. 


\subsubsection{Other Environmental Effects}

1. Bacon, R.F. "Environmental Considerations in Airport Development," in American Society of Civil Engineers Air Transport Division, Airports Key to the Air Transportation Systems, (American Society of Civil Engineers, New York), 1971, 35-48.

2. CLM Systems, Incorporated. Airports and Their Environment, (Government Printing Office, Washington), 1972.

3. East Central Florida Regional Planning Council. Metropolitan Aircraft Noise Abatement Policy Study: Cape Kennedy Regional Airport, Melbourne, Florida, (East Central Florida Regional Planning Council, Winter Park, F1orida), 1971.

4. Environmedia and Steinitz Rogers Associates. Natural Resources Protection Study, (Metropolitan Council of the Twin Cities Area, St. Paul-Minneapolis), 1970.

5. Ha11, P.G. "Regional Planning and Airport Location," in Institute of Civil Engineers, World Airports: The Way Ahead, (Institute of Civil Engineers, London), 1970.

6. Little, A.D. "Environmental Impact Statement," Airport Wor1d, 6, 1973, 48-50.

7. Lynagh, P. "The Airport and the Environment," High Speed Ground Transportation Journa1, 7, 1973, 53-66.

8. McGinty, J.M. and G.L. Snyder. "A Victory for Conservation? The Florida Jetport Controversy, " Traffic Quarterly, 26, 1972, 267-276.

9. Northeastern Illinois Planning Conmission. Metropolitan Aircraft Noise Abatement Policy Study: 0'Hare International Airport, Chicago, Illinois, Technical Report, (Northeastern Illinois Planning Commission, Chicago), 1971 .

10. Plessas, D.J. "Airport Noise: Some Analytic and Policy Perspectives," Land Economics, 49, 1973, 14-21.

11. Robart, C.V. "Environmental Requirements for Airport Projects," Airport Service Management, 11, 1971, 35-39.

12. St. Louis Metropolitan Area Airport Authority. Environmental Impact Statement Pursuant to Section 102 (2), P.L. 91-190, (St. Louis Metropolitan Area Authority, St. Louis), 1972. 
13. Ticer, W.R. 'Legal Methods of Eliminating Certain Undesirable by-Products of the Air Transportation Industry," Natural Resources Journa1, $11,1971,177-194$.

14. Tippetts-Abbett-McCarthy-Stratton. Dallas-Fort Worth Airport: Draft Environmenta1 Impact Statement, (Tippetts-Abbett-McCarthy-Stratton, Arlington, Texas), 1971.

15. United States Argonne National Laboratory. An Air Pollution Impact Methodology for Airports and Attendant Land Use: Fina1 Report, (Uni ted States Argonne Nationa1 Laboratory, Argonne, Illinois), 1973.

16. United States Department of Interior. Environmental Impact of the Big Cypress Swamp Jetport, (Government Printing Office, Washington), 1969.

17. United States Department of the Interior Bureau of Outdoor Recreation. Log of Transportation Projects with Impact on the Environment, (Government Printing Office, Washington), 1971.

18. United States Federal Aviation Administration. Final Findings of the Secretary of Transportation Relative to the Environmental Impact of the Proposed Palmdale International Airport, Government Printing Office, Washington), 1970 .

19. United States Federal Aviation Administration. Sidnay Municipal Airport, Sidney, New York, Environmental Impact Statement, (Government Printing Office, Washington), 1971.

20. West Va1ley Planning Agency, Ontario International Airport Impact Study, (West Valley Planning Agency, San Bernardino, California), 1970.

21. Yannacone, V.J., Jr. and P. Frange11a. "Environmental Concern - the Law and Aviation," in A.J. Cerchione, V.E. Rothe, and J. Vercellino, eds., Master Planning the Aviation Environment, (University of Arizona Press, Tucson), 1970, 121-128. 


\subsection{Highway Investment and Its Effects}

\subsubsection{Administration}

1. American Association of State Highway Officials. AASHO: The First Fifty Years, 1914-1964, (American Association of State Highway Officials, Washington), 1965 .

2. Anonymous. "Iowa Realigns Organizational Structure, "Better Roads, 37, $1967,27-28$.

3. Automotive Safety Foundation. Oklahoma State Highway Management, An Appraisa1, (Automotive Safety Foundation, Washington), 1967.

4. Bartlesmeyer, R.R. "The Importance of the Federal - State Partnership in Highway Transportation," American Highways, 49, 1970.

5. Bartelsmeyer, R.R. "The Highway Official and the Environment," American Highways, $51,1972,13-14$.

6. Barton, C.N. The Technical and Administrative Problems of a State Road Authority, (University of Queensland Press, St. Lucia), 1968.

7. Berg, W.D. An Analysis of the Local Rural Road Administrative System in Illinois, Ph.D. dissertation, Department of Civil Engineering, University of Illinois, 1970.

8. Booz, Allen and Hamilton. Organization and Management Survey: Department of Highways, State of Minnesota, (Booz, A11en and Hamilton, Chicago), 1966.

9. Bridwe11, L.K. "The New Federal Highway Administration - and How It Works," American Road Builder, 44, 1967, 8-11.

10. Burmeister, W.J. "The Changing Image of the Highway Official, "American Road Builder, 44, 1967, 12-13.

11. Cass, S. "Traffic Management in Metropolitan Toronto," Road International, $1970,45-49$.

12. Citizens Committee on Cook County Government. Interim Report on Highways, (Citizens Comnittee on Cook County Government, Chicago), 1968.

13. Cottingham, P.H. Decision Rules in a Public Bureaucracy: An Examination of Highway Planning, Ph.D. dissertation, Department of Economics, University of California, 1969 . 
14. Ernst and Ernst. Financial Management Study: Special Report, (Texas Highway Department, Austin, Texas), 1966.

15. Ernst and Ernst. A Summary of a Research Study of Organization, Procedures, and Intergovernmental Relationships for Nebraska's Highways, Roads, and Streets, (Ernst and Ernst, Chicago), 1967.

16. Ernst and Ernst. A Research Study of Organization, Procedures and Intergovernmental Relationships for Nebraska's Highways, Roads, and Streets, (Ernst and Ernst, Chicago), 1967.

17. Ernst and Ernst. A Research Study of Organization, Procedures and Intergovernmental Relationships for Nebraska's Highways, Roads, and Streets: Appendix, (Ernst and Ernst, Chicago), 1967.

18. Frankland, B. "Coexistence in the Highway Corridor: A Test of Intergovernmental Cooperation," Highway Research Record, 166, 1967, 22-25.

19. Frankland, B. "Socioeconomic Factors and the Highway Decision Process," Highway Research Board Special Report 108, 1970, 30-34.

20. Geiser, K.R., Jr. Urban Transportation Decision Making, Pt. 1. Political Processes of Urban Freeway Controversies, (Massachusetts Institute of Technology Urban Systems Laboratory, Cambridge), 1970.

21. Governor's Commission for Efficiency and Improvement in Government. Organization and Administration of the Georgia Highway Department, (Governor's Cormission for Efficiency and Improvement in Government, Atlanta), 1965.

22. Granum, J.0. "Perspective in Highway Programming - Report on Workshop Meetings," in Proceedings of the American Association of State Highway. Officials, 1970 Convention, (The Association, Washington), 1970 .

23. Harden, J. North Carolina Roads and Their Builders, Vo1. 2, (Superior Stone Company, Raleigh, North Carolina), 1966.

24. Harral, H.D. "Pennsylvania's New Look in Highway Administration," American Highways, $44,1965,29-33$.

25. Highway Management Associates. Management Research Study of the State Highway Department of Georgia, (Highway Management Associates, Madison, Wisconsin), 1965 .

26. Johnson, A.E. "What the Next Generation of Chief Engineers Must Be," American Highways, 45, 1966, 4-6.

27. Johnson, A.E. "The Role of the State Highway Administrator in the 1970's," American Highways, $50,1971,4$.

28. Jorgensen, R. and Associates. Maryland Highway Management; A Report to the Governor and the General Assembly, (Jorgensen, (Roy) and Associates, Gaithersburg, Maryland), 1965.

29. Jorgensen, R. and Associates. Indiana State Highway Comimission Management Improvement Project: Manpower Utilization Study, Plans, and Specifications Department, (Jorgensen, (Roy) and Associates, Gaithersburg, Maryland), 1965. 
30. Management Technology. Management Research Study for the Delaware State Highway Department, (Management Technology, Washington), 1967.

31. New Mexico Highway Department. History and Organization of the New Mexico Highway Department, (Highway Department, New Mexico, Santa Fe, New Mexico), 1972 .

32. Peat, Marwick Mitchell and Company. A Study to Improve Management Functions: Mississippi State Highway Department, (Mississippi State Highway Department, Jackson, Mississippi), 1966.

33. Spring, C., S.E. Farin, and J.C. Houghteling. "Does the State Highway Commission Need Change?" Commonwealth, 10, 1967, entire issue.

34. Thomson, P. "Management Studies - What Can They Do?" Better Roads, 42 , $1972,18-19$.

35. Transportation Task Force. "Highway Department Aided by Business Executives," Public Works, 104, 1973, 86-88. 


\subsubsection{Planning}

1. Barnes, G.D. "Modification of Major Corridor Location Criteria," Transportation Engineering Journal, 99, 1973, 31-41.

2. Bishop, A.B. Socio-Economic and Community Factors in Planning Urban Freeways, Ph.D. dissertation, Department of Civil Engineering, Stanford University, 1969.

3. Frye, F.F. "Route Location Game," Traffic Quarterly, 24, 1970, 45-58.

4. Northwestern University, Transportation Center Library. Freeway Impact on Urban Communities: Selected References, A Bibliography, (Northwestern University, Evanston, Illinois), 1971.

5. Pearce, D. "The Evaluation of Urban Motorway Schemes: A Case Study Southampton," Urban Studies, 10, 1973, 129-143.

6. Riedesel, G.A. and J.C. Cook. "Desirability Rating and Route Selection," Highway Research Record, 305, 1970, 16-25.

7. Reiter, R.E. "The Impact of the Federal Highway Program on Urban Areas," Urban Lawyer, $1,1969,76-88$.

8. Sturman, G.M. "Effects of Highways on Urban Environments," Journal of Environmental Systems, 2, 1972, 61-69.

9. University of Newcastle Upon Tyne. Motorways and Industry: A Report of a Study of the University of Newcastle Upon Tyne, (British Road Federation, London), 1968.

10. Urban Motorways Committee. New Roads in Towns, (Her Majesty's Stationery Office, London), 1972 .

11. Wright, J.R. 'Highways and the Environment: New Problems and New Opportunities," Highway Research News, 1972, 37-46. 


\subsubsection{Pub1ic Opinion}

1. Amir, S. "Conservation Kills a Highway: The Hudson River Expressway Controversy," Discussion Paper No. IV, Research on Conflict in Locational Decisions, (Regiona1 Science Department, University of Pennsylvania, Pennsylvania), 1970 .

2. Amir, S. Highway Location and Pub1ic Opposition, (Israe1 Institute of Technology, Center for Urban and Regional Studies, Haifa), 1972.

3. Amir, S, "Highway Location and Public Opposition," Environment and Behavior, $4,1972,413-436$.

4. Anonymous. "Giving People a Voice on Highways," Business Week, 1968, 111-112.

5. Anonymous. "How do the States Fight Anti-Highway Propaganda," Better Roads, $41,1971,26-29$.

6. Anonymous. "Nevada's Own "West Side Story" Ends We11 After Riotous Start," Highway Research News, 1973, 29-32.

7. Barrow, R.V. The Politics of Interstate Route Selection: A Case Study of Interest Activities in a Decision Situation, Ph.D. dissertation, Politica1 Science, F1orida State University, 1967.

8. Bishop, B.,C.H. Oglesby and G.E. Willeke. "Conmunity Attitudes Toward Freeway Planning: A Study of California's Planning Procedures," Highway Research Record, 305, 1970, 41-52.

9. Bleiker, H., J.H. Suhrbier and M.L. Manheim. "Community Interaction as an Integral Part of the Highway Decision-making Process," Highway Research Record, $356,1971,12-25$.

10. Brancher, D.M. "The Minor Road in Devon - a Study of Visitors' Attitudes," Regiona1 Studies, 6, 1972, 49-58.

11. Burke, D. et. a1. Attitudes, Opinions, and Expectations of Businessmen in a Planned Freeway Corridor, (Texas Transportation Institute, College Station), 1972 .

12. Buffington, et. a1. Experiences and Opinions of Residents Along Elevated, Depressed, and On-Grade Freeway Sections in Houston, Texas, (Texas Transportation Institute, College Station), 1971.

13. Charles River Associates. Public Attitudes Toward Urban Expressway Construction, (Charles River Associates, Cambridge, Massachusetts), 1970. 
14. Citizens' Advisory Committee on Transportation Quality. Community Part1cipation in Highway Planning, (United States Department of Transportation, Washington), 1972 .

15. Cottingham, P. The Measurement of Non-User Benefits in Freeway Planning, (University of California Center for Planning and Development Research, Berkeley, California), 1967.

16. Cottingham, P.H. "Consensus and Conflict in Community Responses to Freeway Planning," High Speed Ground Transportation Journa1, 4, 1970, 51-67.

17. Dansereau, H.K. "Highway Development: Attitudes and Economic C1Imate," Highway Research Record, 187, 1967, $21-32$.

18. Data Unlimited. 'Poll of D.C. Registered Voters' Opinions on Freeway Subway Controversy," in Quayle (Oliver) and Company, Public Opinion in Washington, D.C. Regarding New Freeways, (Government Printing Office, Washington), 1969 .

19. Fellman, G. "Neighborhoods Protest of an Urban Highway," Journal of the American Institute of Planners, 35, 1969, 118-122.

20. Fellman, G. Implications for Planning Policy of Neighborhood Resistance to Urban Renewal and Highway Proposals, (Brandeis University, Department of Sociology, Wa1tham, Massachusetts), 1970.

21. Fellman, G. "Sociological Field Work is Essential in Studying Community Values," Highway Research Record, 305, 1970, 123-132.

22. Fellman, G. and B. Brandt. 'Working-Class Protest Against an Urban Highway: Some Meanings, Limits, and Problems, "Environment and Behavior, 3, 1971, 61-79.

23. Fisher, R.G. and G. Wofford. "Freeway Planning Controversies: The Issue of Community Values," Paper for Annual Meeting, Operations Research Society of America, Los Angeles, California, 1971.

24. Flint, A.G. "Community Values in Highway Planning," Proceedings of Australian Road Research Board, $1968,82-95$.

25. Frankland, B. and S.L. Hill, Community Values: Their Relationship to Land Values and Highway Transportation Planning, (California Division of Highways, Sacramento, California), 1965.

26. Gonen, A. "The Spadina Expressway in Toronto: Decision and Opposition," Discussion Paper No. V, Research on Conflict and Location Decisions, (Department of Regional Science, University of Pennsylvania, Philadelphia), 1970.

27. Gordon, M.E. and R.D. Arvey. "Attitude Measurement in Highway Corridor Studies: Past, Present, and Future," High Speed Ground Transportation Journa 1, 7, 1973, 323-339.

28. Harbert, J.M. "How to Run Over People and Make Them Like It," Highway Research Record, 372, 1971, 45-46. 
29. Heffner, R.E., E. Hunter, and H. Gillespie. "Proceedings of the Committee on Public Information Convention," in Proceedings 1970 Convention, (American Association of State Highway Officials, Washington), 1970, 204-221.

30. Highway Research Board. "Community Values and Socio-Economic Impacts," Highway Research Record, 277, 1969.

31. Hinman, J. "Controversial Facility-Complex Programs: Coalitions, SidePayments, Socia1 Decisions," Discussion Paper No. VIII, Research on Conflict and Location Decisions, (Department of Regional Science, University of Pennsylvania, Philadelphia), 1970.

32. Hughes, W. "Socia1 Benefits Through Improved Transport in Malaya," in E.T. Haefele, ed., Transport and National Goals, (Brookings Institution, Washington), 1969 .

33. Ke1ley, B. The Pavers and the Paved, (Donald W. Brown, New York), 1971.

34. London Borough of Camden. Environmental Effects of Primary Roads in Camden: Greater London Development P1an Pub1ic Inquiry Stage Two, (London Borough of Camden, London), 1971.

35. Lupo, A., F. Colcord, and E.P. Fowler. Rites of Way: The Politics of Transportation in Boston and the U.S. City, (Little, Brown, and Company, Boston), 1971.

36. Maiolo, J.R., ed. Highways and Communities, (Pennsylvania State University, Institute for Research on Land and Water Resources, University Park, Pennsylvania), 1966.

37. Manheim, M. "The Impacts of Highways on Environmental Values," Highway Research Record, 305, 1970, 26-27.

38. Manheim, M.L. "Community Values in Transport Project Planning," Transportation Research Forum, Proceedings - Twelfth Annual Meeting, (Richard B. Cross, Oxford, Indiana), 1971, 297-310.

39. Manheim, M.L., et. a1. Community Values in Highway Location and Design: A Procedural Guide: Final Report, (Massachusetts Institute of Technology, Urban Systems Laboratory, Cambridge), 1971.

40. Mumphrey, A.J., Jr. "The New Orleans Riverfront Expressway Controversy: An Analytical Account," Discussion Paper I, Research on Conflict and Location Decisions, (Department of Regional Science, University of Pennsy1vania, Philade1phia), 1970.

41. Mumphrey, A.J. "A Monte Carlo Simulation of Highway Planning and Citizen Opposition: The Pennsylvania Planning-Opposition Simulation," Discussion Paper No. IX, Research on Conflict and Location Decisions, (Department of Regional Science, University of Pennsylvania, Philadelphia), 1971.

42. Opinton Research Corporation. Public Attitudes Toward Highway Transportation, (Opinion Research Corporation, Princeton, New Jersey), 1971. 
43. Opinion Research Corporation. Public Attitudes Toward Highway Transportation: Summary Analysis of May 1971 ORC Carayan Data, (Opinion Research Corporation, Princeton, New Jersey), 1971.

44. Osborn, M., D.S. Brown, and M. Verman. "The Crosstown is Dead; Long Live the Crosstown? Philadelphia's Controversial Crosstown Expressway,"

Architectural Forum, 35, 1971, 38-45.

45. Parente, F.R. D.C. Transportation Controversies, Values and Integration of Communities, (Consortium of Universities, Urban Transportation Center, Washington), 1970.

46. Peterson, E.T. "Do Freeways Make Good Neighbors?" Traffic Engineering, $43,1973,20-23$.

47. Quayle, 0. and Company. Public Opinion in Washington, D.C., Regarding New Freeways, (Government Printing Office, Washington), 1969.

48. Reiner, T.A., R.J. Sugarman, and J.S. Reiner. The Crosstown Controversy: A Case Study, (University of Pennsylvania Transportation Studies Center, Philadelphia), 1970.

49. Rubin, M. Organized Citizen Participation in Boston, (Boston University Urban Institute, Boston), 1971.

50. Ryan, C.R. The Views and Values of the Community Effected by a Major Transportation Project, (University of Wisconsin, Department of SystemsDesign, Milwaukee), 1972.

51. Seley, J.E. "Spatial Bias: The Kink in Nashville's I 40," Discussion Paper No. III, Research on Conflict in Locational Decisions, (Department of Regional Science, University of Pennsylvania, Philadelphia), 1970.

52. Seley, J.E. "Development of a Sophisticated Opposition: The Lower Manhattan Expressway Issue," Discussion Paper No. II, Research on Conflict in Locational Decisions, (Department of Regional Science, University of Pennsylvania, Philadelphia), 1970.

53. Shaffer, M.T. "Attitudes, Community Values, and Highway Planning," Highway Research Record, 187, 1967, 55-61.

54. Skorpa, L., R. Dodge, C.M. Walton and J. Huddleston. Transportation Impact Research: A Review of Previous Studies and A Recommended Methodology for the Study of Rural Communities, (Council for Advanced Transportation Studies, Austin, Texas), 1974 .

55. Sleight, R.B. "Attitudes Towards Transportation Programs and Proposals: Their Nature and Effects," High Speed Ground Transportation Journal, 4, $1970,117-162$.

56. Sullivan, J.B. and P.A. Montgomery. Evaluating Highway Impacts: How State and Federal officials Evaluate The Environmental Impact of Urban Highways and How Citizens Can Ensure That an Adequate Assessment is Made, (Center for Science in the Public Interest, Washington), 1972 . 
57. Taebe1, D.A. "Citizen Groups, Public Policy, and Urban Transportation," Traffic Quarter1y, 27, 1973, 503-515.

58. United States Bureau of Public Roads. "Public Hearings and Location and Design Approva1," Federa1 Register, 33, 1969, 727-730.

59. United States Federal Highway Administration. "Public Hearings and Location and Design Approva1," Federal Register, 32, 1968, 15663-15666.

60. Walton, L.E., Jr. and J.R. Saroff. Citizen Participation in Public Hearings in Virginia, (Virginia Highway Research Council, Charlottesville), 1971.

61. Weiner, P. et. a1. Non-User Factors in Highway Planning, (University of Connecticut, Hartford, Connecticut), 1970.

62. Weiner, P. and E.J. Deak. "Nonuser Effects in Highway Planning," Highway Research Record, 356, 1971, 55-68.

63. Weiner, P. and E.J. Deak. Environmental Factors in Transportation Planning, (Lexington Books, Lexington, Massachusetts), 1972.

64. Zdon, M. "Citizen Participation in Transportation P1anning," Paper Presented at the Twenty-First Annual Arizona Conference on Roads and Streets, University of Arizona, Tucson, 1972, 136-140. 


\subsubsection{Economic Effects}

1. Anonymous. 'Pane1 Discussion on the Influence of Highways on Industrial Location," Paper for Proceedings of the Canadian Good Roads Association, Ottawa, $1965,280-300$.

2. Ba1com, T.W. The Economic Effects of a Freeway Bypass on Fergus Fa11s, Minnesota, (Minnesota Department of Highways, St. Pau1), 1969.

3. Balcom, T.W. The Economic Impact of a Freeway Bypassing Luverne, Adrian and Worthington, Minnesota, (Minnesota Department of Highways, St. Paul), 1970 .

4. Burkhardt, J.E., A.L. Lago, and J. Rothenberg. Highway Improvement as a Factor in Neighborhood Change, (Resource Management Corporation, Bethesda, Maryland), 1971.

5. Carrol1 College, Department of Economics. Economic Impact Study of Lincoln, Montana, (Carro11 Co1lege, Department of Economics, Helena, Montana), 1965.

6. Christensen, A.H. and B.C. Hartronft. Economic Impact of Interstate Highway 35 on Blackwe11, Oklahoma, (Oklahoma Department of Highways, Oklahoma City), 1966.

7. Christensen, A.H. and B.C. Hartronft. Economic Impact of Interstate Highway 35 on Perry, Oklahoma, (Oklahoma, Department of Highways, Oklahoma City), 1966.

8. Creighton, R.L. and I. Hock, M. Schneider and J. Hyman. "Transportation in Regional Development," High Speed Ground Transportation Journa1, 2, $1968,1-7$.

9. Evans, J.R., K.L. Lueck and G.S. Thompson. An Economic Bypass Study of the St. George, Utah Area, (University of Utah, Bureau of Economic and Business Research, Salt Lake City), 1965.

10. Fleischman, E.R. The Impact After Seven Years of a Highway Improvement in a Sma11 City; Progress Report, (Purdue University, Lafayette, Indiana), 1968 .

11. Franklin, W.D. and L.J. Horn. 'Highway Access and Economic Growth - A Certainty!," American Road Builder, 47, 1970, 12-13.

12. Gamble, H.B. and D.L. Raphael and O.H. Sauerlender. "Direct and Indirect Economic Impacts of Highway Interchange Development," Highway Research Record, $149,1966,42-55$.

13. Goldberg, M.A. and T.D. Heaver. 'Economics of Transportation Corridors: An Empirical Evaluation," Highway Research Record, 356, 1971, 130-138. 
14. Goldstein, S. 'Economic and Social Impact Considerations in Highway Programs," Washington University Urban Law Annual, 1970, 3-19.

15. Hallberg, M.C. and H.H. Taylor. Econometric Analysis of Properties Severed by Interstate Highways, (Pennsylvania State University, Institute for Research on Land and Water Resources, University Park, Pennsy1vania), 1969.

16. Hammer, P. "Economic and Social Considerations," Highway Research Board, Special Report No. 104, (Highway Research Board, Washington), 1969.

17. Harrison, A.J. "Study of the Economic Impact of a Major Motorway Investment, " in European Conference of Ministers of Transport, Report of the Fourth Round Table on Transport Economics, (European Conference of Ministers, Paris), 1969.

18. Harrison, J.W. The Economic Effects of Limited Access Highways and Bypasses: Bibliography, 2nd ed., (Virginia Council of Highway Investigation and Research, Charlottesville, Virginia), 1957.

19. Larsen, F. "Effect of Road Network on Economic Development," Socio-Economic Planning Sciences, 2, 1968, 1-14.

20. Montana College. Economic Impact of the Growth of Tenth Avenue South Upon the Economy of Great Falls, Montana: 1940-1964, (Montana College, Great Falls, Montana), 1965.

21. Montana University, Bureau of Business and Economic Research. Effects of Highway Bypasses in Five Montana Communities, (Montana University, Bureau of Business and Economic Research, Missoula, Montana), 1966.

22. Montgomery, V.E. and W.H. Bergman. The Effect of Highway I-29 on Communities in Southeastern South Dakota, (South Dakota University, Business Research Bureau, Vermillion, South Dakota), 1965.

23. Moore, C.T. and M.L. Mayer. The Expected Economic and Social Impact of Interstate Highways in the Industrial and Commercial Trading Area of Birmingham, Alabama: Final Report, (University of Alabama, Department of Marketing, Huntsville, Alabama), 1965.

24. North Dakota Highway Department. Interstate Highway Impact in the Jamestown Valley City Area: A Statistical Analysis, (North Dakota Highway Department, Bismarck, North Dakota), 1966.

25. North Star Research and Development Institute. The Economic Impact of the Freeways on the Twin Cities Metropolitan Area, (North Star Research and Development Institute, Minneapolis), 1971.

26. Northwestern University Transportation Center Library. Economic Impact of Beltways: Selected References, (Northwestern University, Transportation Center Library, Evanston, Illinois), 1967.

27. Northwestern University Transportation Center Library. Economic Studies of Highway Location in Urban Areas: Selected References, (Northwestern University Transportation Center Library, Evanston, Illinois), 1967. 
28. Ojala, C.F. and P.F. Rizza. "Route 128; A Study of Industry Location Factors," Atlanta Economic Review, 20, 1970, 36-39.

29. Oklahoma Department of Highways. Economic Impact of Interstate Highway 35 on Tonkawa, Oklahoma: Interim Report, (Oklahoma Department of Highways, Oklahoma City), 1968.

30. Putnam, S.H. "The Effect of Changing Transport Facilities on Regional Economic Development: A Case Study of Causal Analysis," Regional Science Association: Papers and Proceedings, 27, 1971, 151-165.

31. Richards, H.A., J.P. Miller, and W.H. Al1io. A Study of Interstate Highways, Frontage Roads and Industry Location, (Texas Transportation Institute, College Station), 1968.

32. Smith, W. and Associates. Maryland Capital Beltway Impact Study: Washington S.M.S.A. and Maryland Counties, Final Report, (Smith (Wilbur) and Associates, Columbia, South Carolina), 1968.

33. Texas Transportation Institute. Economic Aspects of Bypasses and Freeways, (Texas Transportation Institute, College Station), 1969.

34. Thie1, F. "Be1tway and Tax Base Impacts," Journal of the Urban Planning and Development Division, American Society of Civil Engineers, 99, 1973, 105-117.

35. United States Bureau of Public Roads, Economics and Requirements Division. Highways and Economic and Social Changes, Supplement, (United States Bureau of Public Roads, Economics and Requirements Division, Washington), 1964.

36. United States Federal Highway Administration. Benefits of Interstate Highways, (United States Federal Highway Administration, Washington), 1970.

37. United States Federal Highway Administration. Economic and Social Effects of Highways, (Goverment Printing Office, Washington), 1972 .

38. Vockrodt, R.W. The Economic Effects of a Highway Change on Faribault, Minnesota Continued to Mid-Summer 1967, (Minnesota Department of Highways, St. Pau1), 1967.

39. Vockrodt, R.W. The Economic Effects of a Highway Bypass, Clty of Austin, Minnesota, (Minnesota Department of Highways, St. Pau1), 1968.

40. Voorhees, A.M. Computation of Highway Economic Impacts, Exchange Bibliography, No. 67, (Council of Planning Librarians, Montice1lo, Illinois), 1969 .

41. Wallace, R.S. and J.H. Lemly. Analysis of Economic Impact of Highway Change on Two Sma11 Georgia Communities, (Georgia State College, School of Business Administration, Atlanta), 1969.

42. We11s, D.R. An Economic Impact Study of the Effects of Interstate 55 on the Highway-Related Businesses in Five Northern Mississippi Towns, (University of Mississippi, Bureau of Business and Economic Research, University), 1967. 
43. Winfrey, R. and C, Zellner. Summary and Evaluation of Economic Consequences of Highway Improvements, (National Research Council, Highway Research Board, Washington), 1971.

44. Zickefoose, P.W. Economic Survey of Ration, New Mexico, 1958-1966; The "After" Portion of a Highway Relocation, (New Mexico State University, Engineering Experiment Station, University Park, New Mexico), 1968.

45. Zickefoose, P.W. Economic Survey of Anthony, New Mexico-Texas; The "After" Portion of a Highway Relocation Impact Study, (New Mexico State University, Engineering Experiment Station, University Park, New Mexico), 1970. 


\subsubsection{Social Effects}

1. Achtenberg, E. Analysis of the Centralized Relocation Bureau's Crosstown Expressway Survey, (Philadelphia Housing Association, Philadelphia), 1968.

2. Bishop, A.B., C.H. Oglesby and G.E. Willeke. Socio-Economic and Community Factors in Planning Urban Freeways: Final Report, (Stanford University Project on Engineering-Economical Planning, Stanford, California), 1969.

3. Bishop, A.B. Socio-Economic and Community Factors in Planning Urban Freeways, Ph.D. dissertation, Department of Civil Engineering, Stanford University, 1969.

4. Burkhardt, J.E. "Impact of Highways on Urban Neighborhoods: A Model of Social Change," Highway Research Record, 356, 1971, 85-94.

5. Campbe11, E.W. "Socia1 and Economic Factors in Highway Location," Journal of the Highway Division, $92,1966,35-48$.

6. Cohn, B.N. VI Speak, of an Eight Lane Highway and the People who Will be Displaced by it... On the Loss of Home and Neighborhood and the Effect This Has on the Individual, the Family and Society, (Cambridge Civic Association, Cambridge, Massachusetts), 1966.

7. Colony, D.C. Socio-Economic and Environmental Effects of Right-of-Way Acquisition: A Report of Relocation Projects in Cleveland, Ohio, (University of Toledo, Civil Engineering Department, Toledo, Ohio), 1971.

8. Colony, D.C. "Study of the Impact on Household of Relocation From a Highway Right-of-Way, " Highway Research Record, 399, 1972, 12-26.

9. Danie1, Mann, Johnson and Mendenha11. Auburn-Bothe11 Corridor Study, Phase II: Final Report, (Daniel, Mann, Johnson and Mendenha11, Seattle, Washington), 1971 .

10. Dansereau, H.K. "Highway Development: Community Organization and Social Stratification, " Research Report No. 4, (Pennsylvania State University, Institute for Research on Land and Water Resources, University Park, Pennsylvania), 1965.

11. Dansereau, H.K. "Five Years of Highway Research: A Sociological Perspective," Highway Research Record, 75, 1965, 76-81.

12. Dare, C.E. and R.L. Carstens. Freeway Noise, Multiple Land Use, and Aesthetic Study; Cedar Rapid I-380: Final Report, (Iowa State University, Engineering Research Institute, Ames, Iowa), 1973. 
13. Jay, D. "The Cost of Urban Motorways," Town and Country Planning, 38, $1970,98-100$.

14. Ellis, R.H. "Review of the Literature of Social Impacts of Transportation Policies," in Northwestern University Transportation Center, Strategies for the Evaluation of Alternative Transportation Plans, pt. 2, (Northwestern University Transportation Center, Evanston, Illinois), 1967 , 285-304.

15. Fellman, G. and B. Brandt. "A Neighborhood a Highway Would Destroy," Environment and Behavior, 2, 1970, 281-301.

16. Gwilliam, K.M. "The Indirect Effects of Highway Investment," Regional Studies, 4, 1970, 167-176.

17. Hil1, S.L. The Effect of Freeways on Neighborhood; An Analysis of the Relationship of Mobility to Community Values, (California Division of Highways, Sacramento), 1967.

18. Hil1, S.L. "Century Freeway (Watts)," Highway Research Board Special Report $104,1969,68-74$.

19. Horwood, E.M., C.A. Zellner and R.L. Ludwig. Community Conseguences of Highway Improvement, (National Research Council, Highway Research Board, Washington), 1965 .

20. Kanwit, E.L. "Some Aspects of the Social Impact of Urban Transportation," in Transportation: A Service, (New York Academy of Sciences, New York), $1968,81-99$.

21. Kaplan, Gans and Kahn. Social Characteristics of Neighborhoods as Indicators of the Effects of Highway Improvements, (Marshall, Kaplan, Gans, and Kahn, San Francisco, California), 1972.

22. McLean, E.L. and W.G. Adkins. 'Freeway Effects on Residential Mobility in Metropolitan Neighborhoods," Highway Research Record, 356, 1971, 95-104.

23. Miller, T.K. Freeway Impact in Milwaukee, Phase I; Final Report, (Milwaukee Urban Observatory, Milwaukee, Wisconsin), 1972 .

24. National Research Council, Highway Research Board. "Indirect and Sociological Effects of Highway Location and Improvement, 10 Reports Presented at the 43rd Annual Meeting," Highway Research Record, 75, 1965, 102.

25. National Research Council, Highway Research Board. "Indirect Effects of Highway Location and Improvements, 5 Reports Presented at the 44th Annual Meeting, January 11-15, 1965," Highway Research Record, 96, 1965, 58.

26. Northwestern University Transportation Center. The Road and Society; Selected References: A Bibliography, (Northwestern University, Evanston, Illinois), 1969 .

27. Nowlan, D. and N. Nowlan. The Bad Trip: The Untold Story of the Spadina Expressway, (New Press House of Anarisi, Toronto), 1970. 
28. Sale, J, and E. Steinberg. "Effects on Nonrelocated Households of Building a Highway in a Dense Urban Residential Area," Highway Research Record, $356,1971,173$.

29. Salomone, J.J. Before the Highway: Scotlandville, Louisiana, A Black Commity in the Path of an Interstate Highway, (Urban Studies Institute, Louisiana State University, New Orleans), 1971.

30. Sawhil1, R.B. Freeways and Residential Nelghborhoods; A Research Case Study of North Broadway Area, Seattle, Washington, (Automotive Safety Foundation, Washington), 1965 .

31. Sawhi11, R.B. "Freeways and Residential Neighborhoods," Highway Research Record, $149,1966,57$.

32. Sevilla, C.M. Asphalt Through the Model Cities: A Study of Highways and the Urban Poor, L.L.M. Thesis, George Washington University Urban Law Institute, Washington, 1971.

33. Sevilla, C.M. "Aspha1t Through the Model Cities: A Study of Highways and the Urban Poor," Journal of Urban Law, 49, 1971, 297-322.

34. Smith, W. and Associates. A Socioeconomic Study of Highway Development I-287, 195 Corridor, Middlesex and Somerset Counties, New Jersey - 1967, (Smith (Wilbur) and Associates, Columbia, South Carolina), 1968.

35. Theil, F.I. "Conmunity Consequences and Urban Highway Location Decisions," Highway Research Board Special Report, 108, 1970, 27-29.

36. Wallace, McHarg, Roberts and Todd. The Least Social Cost Corridor for Richmond Parkway, (Wallace, McHarg, Roberts, and Todd, Philadelphia), 1968.

37. Washington State University, Engineering Research Division. A Study of the Socia1, Economic and Environmental Impact of Highway Transportation Facilities on Urban Communities, (Washington State University Engineering Research Division, Pullman, Washington), 1968. 


\subsubsection{Effects on Land Use and Land Values}

1. Anonymous. "Exclusion of Increase or Decrease in Value Caused by Public Improvement for Which Lands are Condemned," National Cooperative Highway Research Program Research Results Digest, 45, 1973.

2. Babcock, W.F. and S. Khasnasbis. Land Use Changes and Traffic Generation on Controlled Access Highways in North Carolina: Final Report, Including Highlight Summary of Research, (North Carolina State University at Raleigh, Highway Research Program, Raleigh, North Carolina), 1971.

3. Barden, R. and J.H. Thompson. The Urban Frontier, (Syracuse University, Urban Transportation Institute, Syracuse, New York), 1970.

4. Brinton, J.H., Jr. and J.N. Bloom. Effect of Highway Landscape Development on Nearby Property, (National Research Council, Highway Research Board, Washington), 1969.

5. California Division of Highways. California Land Economic Studies, (California Division of Highways, Sacramento), 1965.

6. Care, C.P. Influences of Interstate Highways on Plant Location in Kentucky: A Survey of Executive Opinion, (American Trucking Association, Washington), 1967.

7. Colony, D.C. Study of the Effect, If Any, of an Urban Freeway Upon Residential Properties Contiguous to the Right of Way, (University of Toledo, Research Foundation, Toledo, Ohio), 1966.

8. Conna11y, J.A. and C.C. Maiburg. "The Washington Capital Beltway and Its Impact on Industrial and Multi-Family Expansion in Virginia," Highway Research Record, $217,1968,9-27$.

9. DeLeon, P. and J. Enns. The Impact of Highways Upon Metropolitan Dispersion: St. Louis, (Rand Corporation, Santa Monica, California), 1973.

10. Downs, A. "Uncompensated Non-Construction Costs Which Urban Highways and Urban Renewal Impose Upon Residential Households," in Hearings before Subcommittee on Roads of the U.S. Congress - Senate, (Government Printing Office, Washington), 1968.

11. Economics and Requirements Division, Office of Research and Development. Narrative Reports of Highway Severance Effects: Index and Summary Analysis, (United States Bureau of Public Roads, Washington), 1967.

12. Eighmy, T.H. The Simulation of Land Use for Highway Interchange Communities, (Pennsylvania State University, The Institute for Research on Land and Water Resources, University Park, Pennsylvania), 1967. 
13. Eyerly, R.W. "Land Use and Land Value in Four Interchange Communities; An Interim Report on the York Study, "in Research Report No. 7, Institute for Research on Land and Water Resources, (Pennsylvania State University, University Park, Pennsylvania), 1966.

14. Fairburn, D.T. A Simulation Model for Land Use Forecasting in an Urban Area. Ph.D. dissertation, Civil Engineering, Syracuse University, 1967.

15. Franklin, W.D. and L.A. Evans. "The Effect of Access on Highway Right of Way Costs and the Determination of Special Benefits," Research Report No. 82-1F, (Texas Transportation Institute, College Station, Texas), 1968 .

16. Franklin, W.D. "The Highway Interchange Complex and Economic Development," Traffic Quarter1y, 24, 1970, 77-91.

17. Frey, J.C., H.K. Dansereau, R.D. Pashek, and A. Twark. "Land Use Planning and the Interchange Community," Bulletin 327, (Highway Research Board), 1962 .

18. Garrison, W.L. and M.L. Marts. Geographic Impact of Highway Improvement: Changes in Transportation, Land Use and Business Patterns, (University of Washington, Seattle), 1958.

19. Garrison, W.L. et. a1. Studies of Highway Development and Geographic Change, (University of Washington Press, Seattle), 1959.

20. Garrison, W.L. Land Uses in the Vicinity of Freeway Interchanges, (University of Washington, Seattle), 1961.

21. Gittinger, C.M. and G.R. Graham. Economic Impact of Interstate Highway 26 on Land Values and Land Uses, With Emphasis Upon the Sections In and Around Columbia and Spartanburg, (University of South Carolina, Bureau of Business and Economic Research, Columbia, South Carolina), 1967.

22. Golden, J.S. Land Values in Chicago: Before and After Expressway Construction, (Chicago Area Transportation Study, Chicago), 1968.

23. Goldberg, M.A. 'Economics of Transportation Corridors: Further Empirical Analysis," Highway Research Record, 410, 1972, 37-51.

24. Hartwick, P.G. and J.M. Hartwick. An Analysis of an Urban Thoroughfare, (Ministry of State for Urban Affairs, Ottawa, Canada), 1971.

25. Hartwick, P.G. and J.M. Hartwick. "An Analysis of an Urban Thoroughfare," Environment and Planning, 2, 1972, 193-214.

26. Hitchock, J.R. and A. Waterhouse. The Impact of Expressways on Adjacent Apartments : A Case Study of Metropolitan Toronto, (University of Toronto York University Joint Program in Transportation, Toronto), 1973.

27. Isibor, E.I. Modeling the Impact of Highway Improvements on the Value of Adjacent Land Parcels: Progress Report, (Purdue University, Lafayette, Indiana), 1969. 
28. Miller, S.F., Jr. Effects of Proposed Highway Improvements on Property Values, (National Research Council, Highway Research Board, Washington), 1971 .

29. Montano, J.M. Recognition of Benefits to Remainder Property in Highway Valuation Cases, (National Research Council, Highway Research Board, Washington), 1970.

30. Mason, J.B. and C.T. Moore. "Commercial Site Selection at Interstate Interchanges, " Traffic Quarterly, 27, 1973, 19-33.

31. Mason, J.B. and C.T. Moore. "An Exploratory Profile of Land-Use Development Patterns at Interstate Interchanges in Alabama: 1964-1970," Review of Regional Studies, III, 1972, 125-140.

32. Mason, J.B. A Selected Bibliography on Interchange Development and Land Use Controls, Exchange Bibliography No. 212, (Council of Planning Librarians, Monticello, Illinois), 1971.

33. Mauldin, B.W. Evaluation Report of Three Hundred Studies of Right of Way Remainders, (Texas Highway Department, Austin), 1967.

34. Moore, C.T., et. al. Land Use Analysis and Consumer Household Shopping Travel Behavior in a Highway Corridor Area: Theoretical Framework, Summary, Findings, and Conclusions, (University of Alabama, School of Commerce and Business Administration, University, Huntsville, Alabama), 1968.

35. Moore, C.T. et. al. Land Use Analysis in a Highway Corridor Area, (University of Alabama, School of Commerce and Business Administration, Huntsville, Alabama), 1968.

36. Moultrop, K. "A Study of the Effect of a By-Pass Road on Business and Land Values: Rhode Island, 1957," Engineering Bulletin, 5, (Rhode Island University, Division of Engineering Research and Development, Kingston, Rhode Island), 1962 .

37. North Carolina Highway Commission. Remainder and Economic Study at Interchanges on I-95: Fina1 Report, (North Carolina Highway Commission, Raleigh North Carolina), 1966.

38. Ohio Department of Highways. Report of Land Economic Studies in the State of Ohio: The North-South Freeway I R-71, (Ohio, Department of Highways, Columbus), 1968 .

39. Passonneau, J.P. "Fu11 Compensation and Transportation Corridor Analysis," Transportation Engineering Journa1, 99, 1973, 393-403.

40. Pipkin, L.S. "Effects of the Interstate System on Property Values - Economic Impact Research," Proceedings of the 47th Annual Tennessee Highway Conference, Knoxville, Tennessee, 1966, 64-90.

41. Sauerlender, O.H., R.B. Donaldson, and R.D. Twark. Factors that Influence Economic Development at Non-Urban Interchange Locations, (Pennsylvania State University, University Park, Pennsylvania), 1967. 
42. Thie1, F. and J. Yasnowsky. "Some Effects of Highway Beautification," Highway Research Record, 233, 1968, 1-15.

43. Washington State Highway Commission. The Effect of a Bypass on Retail Trade : 01ympia-Tumwater, Bypassed Area Compared to Centralia-Chehalis, Bypassed Area and to Puyallup Area, Not Bypassed..., (Washington State Highway Commission, 0lympia), 1965.

44. Wheat, L. F. "The Effect of Modern Highways on Urban Manufacturing Growth," Highway Research Record, 277, 1969, 9-24. 


\subsubsection{Other Environmental Effects}

1. Burt, M.E. Roads and the Environment, Report No. LR 441, Transportation and Road Research Laboratory, Crowthorne, England, 1972.

2. California, Division of Highways. Draft Environmental Impact Statement for the Proposed Freeway Development of Route 101 in the City of Santa Barbara Between Salinas Street and Carrillo Street, 2.7 miles, (California Division of Highways, Sacramento, California), 1971.

3. Cherry, J.D. "The Environment and Highways," Proceedings of Kentucky Highway Conference, (March 20-21, 1972), 53-56.

4. Coleman, D.J. Highways and the Environment: A Bibliography on the Effects of Highways on the Physical, Biological, Recreational, and Aesthetic Environments and Techniques for the Analysis of These Impacts, Exchange Bibliography, No. 394, (Council of Planning Librarians, Monticello, Illinois), 1973 .

5. Flowerdew, A.D.J. and A. Hammond. "City Roads and the Environment," Regional Studies, 7, 1973, 123-136.

6. Graeub, W.C., A.A. Grant and R. Winfrey. "Impact of Environmental Controls on Highways," Transportation Engineering Journa1, 98, 1972, 263-274.

7. Hamilton, L. and D.S. Lacate. "Ecologically Alert Highway P1anning," Better Roads, 41, 1971, 17-19.

8. Harvard University, Department of Landscape Architecture. Comprehensive Highway Planning:A Study of Qualitative Factors in Rural Highway Location Methodology, (Harvard University, Department of Landscape Architecture, Cambridge, Massachusetts), 1969.

9. Isaacson, L, and B.L. Peterson. Park and Recreational Facilities: Their Consideration as an Environmental Factor Influencing the Location and Design of a Highway, (Government Printing Office, Washington), 1971.

10. Khanna, S.D. "Effects of Highways on Surface and Subsurface Waters," Public Works, 104, 1973, 71-73.

11. Lassiere, A. and P. Bowers. "Studies on the Socia1 Costs of Urban Road Transport," Summary of the discussion of the Eighteenth Round Table on Transport Economics, (European Conference of Ministers of Transport, Paris), 1972. 
12. Lloyd, I.C. "Environmental Considerations in Highway Location and Design," in International Road Federation, World Survey of Current Research and Development on Roads and Road Transport: 1971, (International Road Federation, Washington), 1971.

13. Netherton, R.D. "Transportation Planning and the Environment," Washington University Urban Law Annual, 1970, 65-84.

14. Plowman, E. G., and E.A. Imhoff. "The Inevitable Compromise - Highways Vs. the Envi ronment," Traffic Quarterly, 26, 1972, 177-188.

15. Schmidt, R.H., Jr. The Impact of Freeways on California's Rural Landscape, Ph.D. dissertation, Department of Geography, University of California at Los Angeles, 1968.

16. Shane, J.N. "Environmental Litigation in 1971, " Highway Research Circular, 1972 , entire issue.

17. Sherwood, P.T. "Roads, Traffic and the Environment," Roads and Road Construction, 49, 1971, 137-142.

18. Watkins, L.H. "Conurbation Transport and Environmental Pollution," in Proceedings of Fifth Symposium on the Future of Conurbation Transport, October 19-21, 1971 .

19. Weiner, P. et. al. Non-User Factors in Highway Planning, (University of Connecticut, Hartford, Connecticut), 1970.

20. Weiner, P. and E.J. Deak. Environmental Factors in Transportation Planning, (Lexington Books, Lexington, Massachusetts), 1972. 
a

4 


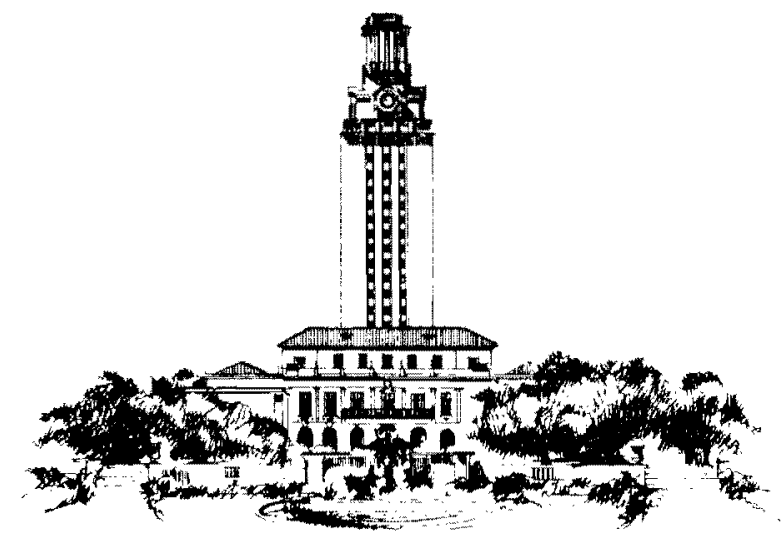

Council for Advanced Transportation Studies

THE UNIVERSITY OF 'TEXAS AT AUSTIN 